\title{
SUVREMENI IZAZOVI U PROVOĐENJU SOCIJALNE POLITIKE S POSEBNIM NAGLASKOM NA MJERE SOCIJALNE INTERVENCIJE
}

\author{
Doc. dr. sc. Vanja Smokvina* \\ Magdalena Čunčić, mag. iur.**
}

\author{
UDK: 331.359:349.2(497.5) \\ https://doi.org/10.30925/zpfsr.40.3.9 \\ Ur.: 11. listopada 2019. \\ Pr.: 9. prosinca 2019. \\ Pregledni rad
}

\begin{abstract}
Sažetak
Autori u radu ističu važnost socijalnih intervencija kao mjera socijalne politike u svladavanju izazova suverenoga društva. Naglasak je dan na mjere poput dječjeg doplatka, naknada za roditeljski dopust, subvencioniranje stambenih kredita mladih obitelji te druge mjere pronatalitetne i obiteljske politike ne samo na državnoj, već i na lokalnoj razini.
\end{abstract}

Ključne riječi: socijalna politika; socijalne investicije; socijalna Hrvatska; Europska unija

\section{1. $U V O D$}

Nakon Drugog svjetskog rata javlja se zamisao o državi blagostanja s dva važna temelja: punom zaposlenosti i stabilnom obitelji, u sklopu glavnoga cilja, suzbijanja siromaštva. ${ }^{1}$ To se može postići i osigurati učinkovitim mjerama socijalne politike, odnosno organiziranom djelatnosti države i drugih društvenih čimbenika u cilju prevladavanja socijalnih rizika, pomoći siromašnima i isključenim pojedincima te socijalnim skupinama, ujednačavanjem životnih šansi odnosno, općenito, unaprjeđivanjem socijalne dobrobiti građana. Glavni instrumenti socijalne politike su socijalna prava i socijalni programi kojima se ona praktično ostvaruje. ${ }^{2}$ Drugim riječima, cilj je socijalne politike poboljšanje životnih i radnih uvjeta svih građana.

Temelj za formiranje sustava socijalnog osiguranja su socijalni slučajevi

* Dr.sc. Vanja Smokvina, docent, Sveučilište u Rijeci, Pravni fakultet; vsmokvina@pravri.com.

** Magdalena Čunčić, mag. iur.; magdalenacuncic@gmail.com.

Ovaj je rad sufinanciralo Sveučilište u Rijeci projektom „Pravni aspekti digitalne transformacije društva", uniri-drustv-18-252. Rad predstavlja skraćeni i dorađeni diplomski rad studentice Magdalene Čunčić (mentor: doc. dr. sc. Vanja Smokvina) pod nazivom „Socijalna prava s posebnim osvrtom na Zakon o rodiljnim i roditeljskim potporama i mjere populacijske politike u Republici Hrvatskoj“, obranjenog u srpnju 2019. godine na Sveučilištu u Rijeci, Pravnom fakultetu.

1 Učur, M. Đ., Socijalno pravo, Zagreb, Informator, 2000., str. 1.

2 Puljiz, V. i dr., Socijalna politika Hrvatske, Zagreb, Pravni fakultet, 2008., str. XI. 
ili socijalni rizici kojima građani mogu biti pogođeni, koji ne moraju uvijek biti iznenađujući ili neplanirani. Rizike definiramo kao buduće ili sadašnje stanje, uvijek više ili manje negativno, u smislu zadovoljavanja uvjeta života, bez obzira na to jesu li bili željeni (planirani) ili neplanirani (neželjeni). ${ }^{3}$ Različite su podjele socijalnih rizika prema uzrocima njihovih pojava, koji mogu biti fiziološki (npr. bolest, starost, smrt, invaliditet, majčinstvo), obiteljski (npr. povećanje broja djece u obitelji, zaposlenost ili nezaposlenost roditelja, prihodi roditelja, zdravlje djece i roditelja), socijalni rizici (npr. rat, nezaposlenost, ekonomske krize), profesionalni rizici (npr. ozljeda na radu, profesionalna bolest, gubitak posla) pa i rizici koji nastaju prirodnim katastrofama (npr. požar, potres, poplava). Socijalno osiguranje obuhvaća mnoga područja, ovisno o tome kojim su rizicima pojedinci pogođeni, a osiguranje obiteljskih dodataka koje se odnosi i na mjere pronatalitetne politike te pomoći obitelji s djecom jedno je od tih područja.

Glavna je hipoteza ovoga rada da se razvojem suvremenoga društva pojavljuje potreba za novim oblicima socijalnih ulaganja, odnosno socijalnih investicija u sklopu sustava socijalne politike. Stoga će autori analizirati strateške dokumente Europske unije (u daljnjem tekstu: EU), ali i pravni okvir te strateške smjernice (socijalnih) politika Republike Hrvatske (u daljnjem tekstu: RH). Posebnu važnost dat će mjerama, socijalnim ulaganjima, kojima se nastoji uskladiti profesionalni i obiteljski život u RH s osobitim naglaskom na obiteljske i populacijske politike, a osobito pronatalitetne politike usmjerene ponajprije na žene i mlade obitelji s djecom.

\section{NOVI SOCIJALNI RIZICI I SOCIJALNE INVESTICIJE (ULAGANJA) U SUSTAVU SOCIJALNE POLITIKE}

Socijalni rizici se s vremenom mijenjaju, a s time se nužno trebaju mijenjati i prilagođavati socijalne politike država. Veliki su izazovi pred državama i usklađivanje socijalne politike ekonomskim krizama u kojima uglavnom dolazi do rezanja socijalnih troškova. Socijalne države u Europi dugo odgađaju „ozbiljnije suočavanje“ s posljedicama novih socijalnih rizika povezanih s promjenama u obitelji, novim demografskim uvjetima niskoga fertiliteta, starenja populacije i propusta tržišta u privatnom pružanju socijalne sigurnosti. ${ }^{4}$ Te su promjene tipične za postindustrijska društva. „Došlo je do značajnog preokreta trenda u zapošljavanju, od dominantnog rasta zapošljavanja u industriji prema rastu zapošljavanja u uslugama u Europi u posljednjih nekoliko desetljeća“. ${ }^{5}$ Taj se proces može definirati kao deindustrijalizacija i tercijarizacija zaposlenosti. „Naime, sve se manje može očekivati stabilno zaposlenje tijekom cijele radne karijere. Više nego ikad prije ljudi mogu očekivati isprekidane

3 Učur, M. Đ., op. cit., str. 61.

4 Hemerjick, A., Two or three ways of welfare state transformation, str. 55, u: Towards a social investment welfare state? Ideas, Policies and Challenges, N. Morel, B. Palier, J. Palme (ur.), Bristol, The Policy Press, 2012., prema Babić, Z. i Baturina, D., Koncept socijalnih investicija kao odgovor na krizu i nove izazove socijalne države: trendovi i perspektive, Revija za socijalnu politiku, vol. 23, 1/2016, str. 40.

5 Cousins, M., European Welfare States: Comparative Perspectives, London, Sage, 2005., prema Babić Z. i Baturina, D., op. cit., str. 41. 
radne karijere, koje podrazumijevaju veće nestabilnosti i češće izmjene razdoblja zaposlenosti i nezaposlenosti, kao i rad na određeno vrijeme te rad sa skraćenim radnim vremenom." "Živimo u vremenu u kojem se struktura obitelji uvelike mijenja, pa tako u velikom broju zemalja EU-a, pa i u RH, dolazi do povećanja stope razvoda (tablica 1.), jedno-roditeljskih obitelji te povećanja broj samačkih kućanstava (tablica 2.).

Tablica 1. Sklopljeni i razvedeni brakovi (izvor: DZS) ${ }^{7}$

\begin{tabular}{|l|c|c|c|c|}
\hline \multirow{2}{*}{} & \multicolumn{2}{|c|}{ Sklopljeni brakovi } & \multicolumn{2}{c|}{ Razvedeni brakovi } \\
\cline { 2 - 5 } & ukupno & na 1000 stanovnika & ukupno & na 1000 sklopljenih \\
\hline 1950. & 37995 & 9,9 & 3137 & 83 \\
\hline 1960. & 36761 & 8,9 & 4811 & 131 \\
\hline 1970. & 37319 & 8,5 & 5333 & 143 \\
\hline 1980. & 33310 & 7,3 & 5342 & 160 \\
\hline 1990. & 27924 & 5,8 & 5466 & 201 \\
\hline 2000. & 22017 & 5,0 & 4883 & 221 \\
\hline 2005. & 22138 & 5,0 & 5058 & 238 \\
\hline 2010. & 21294 & 4,8 & 6010 & 303 \\
\hline 2015. & 19834 & 4,9 & 7036 & 344 \\
\hline 2016. & 20467 & & & \\
\hline
\end{tabular}

Tablica 2. Privatna kućanstva prema broju članova, popisi stanovništva 1953.-2011. (izvor: DZS) ${ }^{8}$

\begin{tabular}{|l|c|c|c|c|c|c|c|}
\hline & \multicolumn{7}{|c|}{ Popisi stanovništva } \\
\cline { 2 - 8 } & $\mathbf{1 9 5 3 .}$ & $\mathbf{1 9 6 1 .}$ & $\mathbf{1 9 7 1 .}$ & $\mathbf{1 9 8 1 .}$ & $\mathbf{1 9 9 1 .}$ & $\mathbf{2 0 0 1 .}$ & $\mathbf{2 0 1 1 .}$ \\
\hline Ukupno & 1.031 .910 & 1.167 .586 & 1.289 .325 & 1.423 .862 & 1.544 .250 & 1.477 .377 & 1.519 .038 \\
\hline$\%$ & 100,0 & 100,0 & 100,0 & 100,0 & 100,0 & 100,0 & 100,0 \\
\hline $\begin{array}{l}\text { Samačka } \\
\text { kućanstva }\end{array}$ & 14,1 & 16,0 & 15,5 & 16,0 & 17,8 & 20,8 & 24,6 \\
\hline 2 člana & 16,7 & 17,7 & 18,6 & 21,1 & 22,5 & 23,6 & 25,6 \\
\hline 3 člana & 18,8 & 19,4 & 21,1 & 21,5 & 20,2 & 19,0 & 18,8 \\
\hline 4 člana & 18,0 & 19,1 & 20,8 & 22,6 & 23,5 & 20,6 & 17,3 \\
\hline 5 članova & 13,3 & 12,9 & 12,1 & 10,1 & 9,2 & 9,2 & 8,0 \\
\hline
\end{tabular}

6 ibid., str. 42.

7 Državni zavod za statistiku Republike Hrvatske, Žene i muškarci u Hrvatskoj 2018., dostupno na: https://www.dzs.hr/Hrv_Eng/menandwomen/men_and_women_2018.pdf (23.07.2019.).

8 Državni zavod za statistiku Republike Hrvatske, Privatna kućanstva prema broju članova, dostupno na: https://www.dzs.hr/Hrv/censuses/census2011/results/htm/Usp_06_HR.htm (23.07.2019.). 


\begin{tabular}{|l|c|c|c|c|c|c|c|}
\hline 6 članova & 8,5 & 7,5 & 6,5 & 5,2 & 4,4 & 4,3 & 3,5 \\
\hline $\begin{array}{l}7 \text { i više } \\
\text { članova }\end{array}$ & 10,6 & 7,4 & 5,4 & 3,5 & 2,4 & 2,5 & 2,2 \\
\hline $\begin{array}{l}\text { Prosječan } \\
\text { broj članova } \\
\text { kućanstva }\end{array}$ & 3,8 & 3,6 & 3,4 & 3,2 & 3,1 & 3,0 & 2,8 \\
\hline
\end{tabular}

S druge strane, udio starije populacije stalno se povećava jer se napretkom medicine i poboljšanjem zdravstvene zaštite produljio očekivani životni vijek čovjeka što je dodatni pritisak na zdravstveni i mirovinski sustav, a time i na učinkovitost čitave socijalne politike neke države. Osim toga, razvojem društva udio žena na tržištu rada i udio visoko obrazovanih žena (tablica 3.) kontinuirano raste, što logično dovodi do nužnosti usklađivanja profesionalnog i obiteljskog života roditelja o čemu će još biti govora u nastavku.

Tablica 3. Studenti koji su diplomirali na visokim učilištima (izvor: DZS) ${ }^{9}$

\begin{tabular}{|c|c|c|c|c|c|}
\hline & \multirow{2}{*}{ Ukupno } & \multirow{2}{*}{ Žene } & \multirow{2}{*}{ Muškarci } & \multicolumn{2}{|c|}{ Spolna raspodjela, \% } \\
\hline & & & & žene & muškarci \\
\hline 1960. & 3488 & 1110 & 2378 & 31,8 & 68,2 \\
\hline 1970. & 8509 & 3921 & 4588 & 46,1 & 53,9 \\
\hline 1980. & 13955 & 6228 & 7727 & 44,6 & 55,4 \\
\hline 1990. & 9706 & 5213 & 4493 & 53,7 & 46,3 \\
\hline 2000. & 13510 & 7506 & 6004 & 55,6 & 44,4 \\
\hline 2005. & 18190 & 10845 & 7345 & 59,6 & 40,4 \\
\hline 2006. & 19566 & 11594 & 7972 & 59,3 & 40,7 \\
\hline 2007. & 20969 & 12180 & 8789 & 58,1 & 41,9 \\
\hline 2008. & 25573 & 15014 & 10559 & 58,7 & 41,3 \\
\hline 2009. & 30156 & 17681 & 12475 & 58,6 & 41,4 \\
\hline 2010. & 32378 & 19679 & 12699 & 60,8 & 39,2 \\
\hline 2011. & 36488 & 21354 & 15134 & 58,5 & 41,5 \\
\hline 2012. & 36964 & 21991 & 14973 & 59,5 & 40,5 \\
\hline 2013. & 35252 & 20763 & 14489 & 58,9 & 41,1 \\
\hline 2014. & 33741 & 20210 & 13531 & 59,9 & 40,1 \\
\hline 2015. & 34745 & 20700 & 14045 & 59,6 & 40,4 \\
\hline 2016. & 32895 & 19718 & 13177 & 59,9 & 40,1 \\
\hline
\end{tabular}

Sve prethodno navedeno novi su socijalni rizici s kojima se danas suočavaju moderne države. Oni imaju tendenciju utjecaja na ljude u mlađim razdobljima života, obično pri ulazu na tržište rada i uspostavljanju svoga položaja unutar njega te $u$ trenutku preuzimanja odgovornosti u razdoblju izgradnje obitelji. Uključuju rizike

9 Državni zavod za statistiku Republike Hrvatske, Žene i muškarci u Hrvatskoj 2018., dostupno na: https://www.dzs.hr/Hrv_Eng/menandwomen/men_and_women_2018.pdf (23.07.2019.), str. 31. 
povezane s integracijom na tržište rada, kao i rizike povezane s obiteljskim životom. ${ }^{10}$ Tzv. „stari“ socijalni rizici kao što su bolest, starost, invaliditet ili nezaposlenost i danas su prevladavajući dio socijalnih programa država u Europi. Takvi se programi nazivaju i kompenzacijskim programima jer su usmjereni na popravljanje posljedica koje su nastupile pojavom određenih rizika. Nasuprot tomu, javlja se novi pristup, a to je koncept socijalnih investicija (ulaganja). ${ }^{11} \mathrm{U}$ tom smislu, koncept socijalnih investicija ide za pomirbom zahtjeva za ekonomskom učinkovitošću tržišta s jedne strane i ,socijalne orijentacije“ modernih socijalnih država s druge. Postavlja se imperativ da se socijalna politika odmakne od obrasca pasivnog post festum djelovanja na društvene promjene. Konačno, na socijalna ulaganja gleda se kao na ulaganja koja jačaju kapacitet pojedinaca da se spremni aktivno suoče sa životnim rizicima. ${ }^{12}$

Važnost koncepta socijalnih investicija, pogotovo kada znamo za velike nejednakosti država eurozone kada je riječ o razmjeni rada, ${ }^{13}$ prepoznao je i EU u svojim dokumentima. „U okviru strategije Europa 2020 za pametan, održiv i uključiv rast utvrđuju se ciljevi kojima bi se iz siromaštva i socijalne isključenosti izvuklo najmanje 20 milijuna ljudi te povećala stopa zaposlenosti stanovništva u dobi od 20 do 64 godine na $75 \%$ ". ${ }^{14}$ Europska je komisija kao potporu strategiji 2013. pokrenula Paket za socijalno ulaganje s naglaskom na važnost ulaganja u ljudski kapital u obrazovanju. Komisija s pomoću paketa mjera za socijalno ulaganje državama članicama nudi smjernice za modernizaciju sustava socijalne skrbi u cilju socijalnog ulaganja tijekom cijeloga života. ${ }^{15}$ Taj je paket usklađen i nadopunjen Paketom mjera za zapošljavanje, ${ }^{16}$ Paketom mjera za zapošljavanje mladih ${ }^{17}$ te Bijelom knjigom o mirovinama $^{18}$. Glavna područja socijalnih investicija u zemljama EU-a su ulaganja u aktivnu politiku zapošljavanja, ulaganja u obitelj i djecu te posljednje, no ništa manje važno, ulaganje u obrazovanje. Nažalost, u sva tri područja RH zaostaje za europskim prosjekom. Tako, npr. na ulaganje u programe za obitelj i djecu RH je prema podatcima Eurostata 2013. izdvojila tek 1,6 \% BDP-a dok je europski prosjek 2,2 \% BDP-a. Zemlje koje najviše izdvajaju su Danska i Luksemburg s 3,6 \% BDP-a (graf 1.).

10 Babić, Z. i Baturina, D., op. cit., str. 43.

11 Europska komisija, Ulaganje u socijalnu politiku, dostupno na: https://ec.europa.eu/social/ main.jsp?catId=1044 (10.07.2019.).

12 Babić, Z. i Baturina, D., op. cit., str., 45.

13 Rubinić, I. i Tajnikar, M., Labour force exploitation and unequal labour excahnge as the root cause of the Eurozone's inexuality, Društvena istraživanja, vol. 28, 2/2019, str. 207-228.

14 Europska komisija, Socijalna zaštita i socijalno uključivanje, dostupno na: https://ec.europa.eu/ social/main.jsp?catId=750\&langId=hr (23.07.2019.).

15 loc. cit.

16 Europska komisija, Paket mjera za zapošljavanje, dostupno na: https://ec.europa.eu/social/ main.jsp?catId=1039\&langId=en (23.07.2019.).

17 Europska komisija, Zapošljavanje, socijalna pitanja i uključenost, dostupno na: https:// ec.europa.eu/social/main.jsp?langId=en\&catId=1036\&newsId=1731\&furtherNews=yes (23.07.2019.).

18 European Commission, EU sets out plans for adequate, safe and sustainable pensions, dostupno na: https://ec.europa.eu/social/main.jsp?langId=en\&catId=89\&newsId=1194\&furtherNews=yes. 


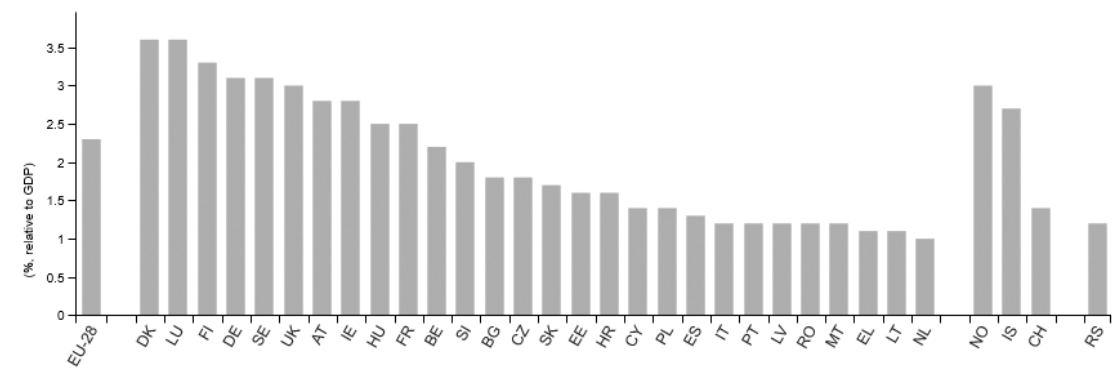

Graf 1. Udio izdataka za obitelj i djecu u BDP-u u zemljama EU, 2013. (izvor: Eurostat) ${ }^{19}$

Nužnim se stoga čini modernizirati socijalnu državu u RH u smislu određenoga zaokreta prema programima socijalnih ulaganja te povećati izdvajanja za obrazovanje, djecu i obitelj kao i programe aktivne politike zapošljavanja, kako bi se potaknuli pozitivni razvojni učinci programa socijalne politike s jedne strane te preventivni učinci socijalnih programa u suočavanju s novim socijalnim rizicima s druge.$^{20}$ Osim u navedenim područjima, RH zaostaje i za državama članicama EU-a i po izdatcima u svim drugim područjima socijalne zaštite (graf 2.).

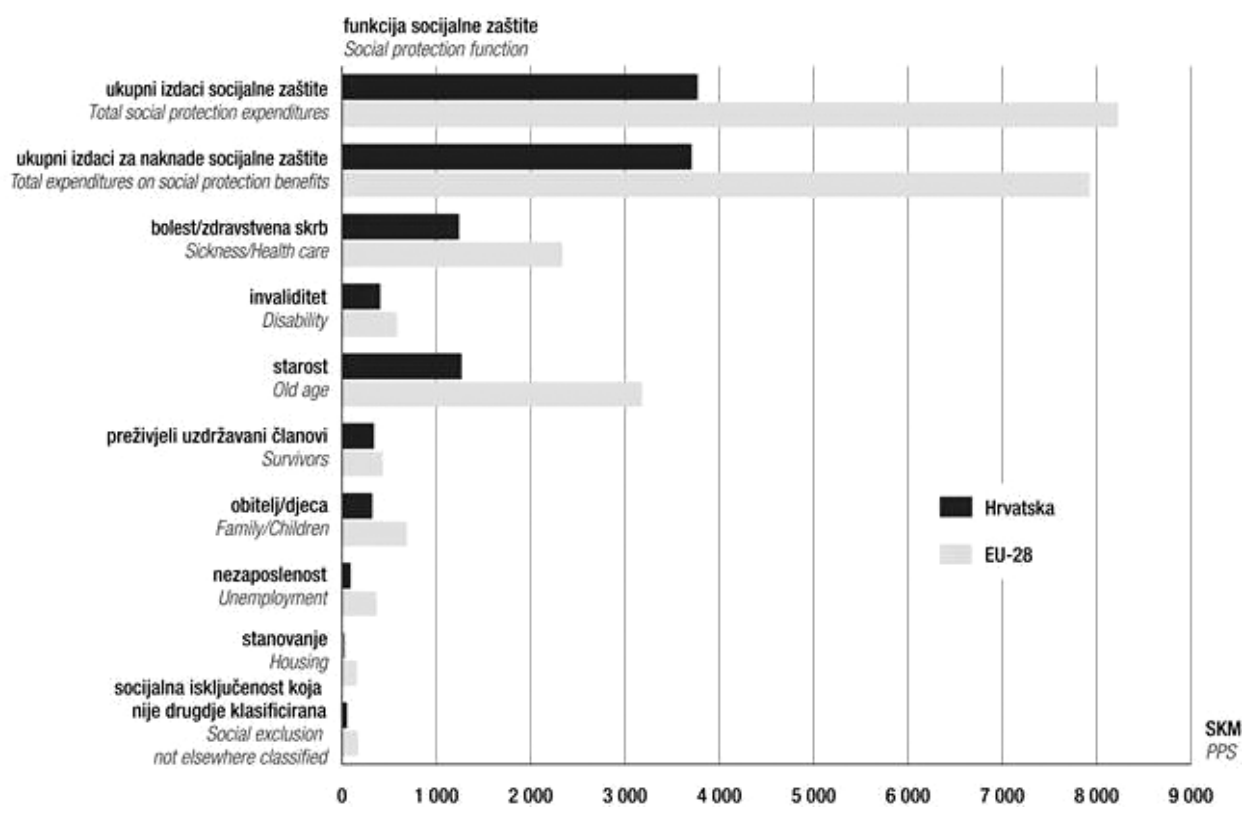

Graf 2. Izdatci za socijalnu zaštitu po stanovniku, EU-28 i Republike Hrvatske prema funkcijama socijalne zaštite, izraženi u standardu kupovne moći (SKM) u 2016. (izvor: DZS) ${ }^{21}$

19 Eurostat, Social protection statistics - family and children benefits, dostupno na: https://ec.europa.eu/eurostat/statistics-explained/index.php?title=Social_protection statistics_-_family_and_children_benefits (23.07.2019.).

20 Babić, Z. i Baturina, D., op. cit., str. 56.

21 Državni zavod za statistiku, Socijalna zaštita u Republici Hrvatskoj u 2017., Zagreb, Državni zavod za statistiku, 2019., dostupno na: https://www.dzs.hr/Hrv_Eng/ 
Obiteljske politike, politike usklađivanja profesionalnog i obiteljskog života i pronatalitetne politike ključne su za suočavanje s pojavom prethodno navedenih rizika za sve države članice EU-a. Problem postizanja učinkovite obiteljske i populacijske politike kojima će se s jedne strane osigurati kvalitetniji život obiteljima, posebno obiteljima s djecom, a s druge utjecati na povećanje stope fertiliteta i time potaknuti pozitivne demografske trendove, vrlo je aktualan, ali i vrlo složen. U nastavku rada autori će nastojati prikazati kako se RH pokušava suočiti s tom kompleksnom problematikom, ukazati na neke pozitivne pomake, ali i mnoge probleme koji su prisutni, pritom dajući primjere i usporedbu s drugim državama članicama EU-a, odnosno načinom na koji su razvijenije države EU-a pristupile rješavanju aktualne problematike.

\section{SOCIJALNA (OBITELJSKA) POLITIKA HRVATSKE}

„Obiteljska se politika definira kao cjelovit i sustavan skup mjera koje djeluju u korist obitelji, posebno obitelji s djecom. Mjere obiteljske politike pomažu u prevladavanju nepovoljnih ekonomskih, socijalnih, zdravstvenih, stambenih situacija; one ublažavaju financijski teret koji obiteljima donose djeca, omogućavaju usklađivanje obiteljskih i radnih obveza te, općenito, štite trudnice, mlade majke i djecu.“"22 Cilj na koji je usmjerena obiteljska politika poboljšanje je kvalitete života obitelji i upravo se po tome razlikuje od pojma populacijske politike. Populacijska je politika usmjerena na demografske promjene, odnosno na povećanje ili smanjenje broja stanovnika. U državama članicama EU-a uglavnom se radi o populacijskim politikama koje su usmjerene na povećanje broja stanovnika pa je tako i u RH. Ipak, obiteljska i populacijska politika usko su povezane i utječu jedna na drugu, a mnoge mjere obiteljske politike u RH ujedno su i populacijske, odnosno pronatalitetne. Povijesno gledano, važnu ulogu u brizi o obitelji, posebno djeci imale su različite religijske organizacije, dok danas govorimo o obiteljskoj politici koja je dio državne politike. „Postoje, ipak, dosta velike razlike između nordijskih zemalja koje su razvijale tip obitelji s dva hranitelja i bivših socijalističkih zemalja, kao i razlike između pojedinih socijalističkih zemalja, što relativizira argumente o istom modelu obiteljske politike.“223 Specifično za RH, posebno početkom devedesetih godina prošloga stoljeća, u obiteljskoj se, ali i socijalnoj politici općenito osjećao utjecaj socijalizma, no obiteljska se politika razvija i mijenja u skladu s ekonomskom situacijom i promjenama vlasti u državi. Pokazalo se, naime, da su obiteljska i populacijska politika veoma važno polje nadmetanja političkih stranaka u predizbornim kampanjama, dok su istodobno zapostavljane objektivne analize na kojima treba graditi dugoročnu i realno utemeljenu obiteljsku i populacijsku politiku. ${ }^{24}$ Ipak, RH je od 1. srpnja 2013. članica EU-a i svoje cjelokupno zakonodavstvo, a time i ono iz područja obiteljske

publication/2019/10-01-05_01_2019.htm.

22 Stropnik, N., Obiteljske politike u Europi, Revija za socijalnu politiku, vol. 3, 2/1996, str. 105 prema Puljiz, V., Obiteljska politika, str. 317., u: Socijalna politika, Puljiz, V. (ur.), Zagreb, Pravni fakultet, 2005.

23 Puljiz, V., Socijalna politika Hrvatske, op. cit., str. 284

24 ibid., str. 328. 
politike, koje se obrađuje u ovome radu, a tiče se direktiva EU-a, morala je uskladiti s pravom Unije (EU acquis). Unatoč tomu još uvijek bitno zaostaje za ostalim državama članicama EU-a u području ulaganja u socijalnu zaštitu djece i obitelji (graf 2., supra).

\section{ZAPOSLENOST (ŽENA) I OBITELJ - USKLA円IVANJE PROFESIONALNOG I OBITELJSKOG ŽIVOTA}

O potrebi usklađivanja profesionalnog i obiteljskog života došlo je zbog važnih demografskih problema na čitavom prostoru EU-a. Naime, kao što je već ranije spomenuto, udio starije populacije u ukupnom stanovništvu u stalnom je porastu što je veliki pritisak na područje socijalnog osiguranja, a s druge se strane smanjuje broj radno sposobnog stanovništva i broj mladih na tržištu rada. Unija je kao rješenje predložila poticanje povećanja stope zaposlenosti starije populacije, ali i žena. No, s druge strane smatra se da bi navedeno moglo dovesti do još dodatnog smanjenja stope „fertiliteta. “25 Cilj je postići s jedne strane povećanje stope zaposlenosti žena, a s druge povećati stopu fertiliteta. No da bi se to postiglo potrebne su mjere koje bi roditeljima, ali ponajviše ženama omogućile usklađivanje poslovnih i obiteljskih obveza.

Kada govorimo o obiteljskom životu, s obzirom na hranitelja obitelji, razlikuje se nekoliko modela obitelji: model muškog hranitelja obitelji (muškarac je taj koji ekonomski doprinosi, a žena ostaje kod kuće i brine o djeci i kućanstvu), modernizirani model muškog hranitelja (muškarac radi puno radno vrijeme, a žena u skraćenom radnom vremenu pa tako doprinosi obitelji kao sekundarni hranitelj, ali samim time ima nižu plaću od muškarca) i dvohraniteljski model obitelji (oba roditelja ekonomski doprinose obitelji podjednako, ali razlike su u poslovima u obitelji, odnosno kućanskim poslovima i brizi za djecu, u jednom tipu obitelji te poslove obavljaju podjednako muškarac i žena, a u drugom dolazi do dvostruke opterećenosti žene, odnosno, očekuje se da žena uz ekonomski doprinos obitelji i u potpunosti preuzme brigu o kućanstvu i djeci). ${ }^{26}$

U razvijenim zemljama danas se sve više teži dvohraniteljskom modelu obitelji. Dvohraniteljski oblik obitelji u kojima dolazi do ravnopravnoga sudjelovanja $\mathrm{u}$ ekonomskom doprinosu i brizi za kućanstvo ipak je vrlo rijedak i nalazimo ga uglavnom u nordijskim zemljama. To su zemlje u kojima je tranzicija od tradicionalnoga modela muškoga hranitelja prema modernom obliku obitelji s dva hranitelja već završila. „U društvima poput hrvatskog, gdje su očekivanja o ulozi žene da se velikim dijelom brine o djeci visoka, a institucionalna potpora i infrastruktura zaposlenoj ženi majci nedostatna, njihov položaj sve je gori. Razlike među zemljama u brzini iščezavanja tradicionalnog modela muškog hranitelja i njihove zamjene dvohraniteljskim

25 Općenito plodnost, rodnost. U demografiji, broj živorođene djece u odnosu na broj žena u plodnom razdoblju. Pojam fertilno razdoblje ili razdoblje prokreacije, označuje u životu žene ono razdoblje kad je ona fiziološki sposobna sudjelovati u reprodukciji. Leksikografski zavod Miroslav Krleža, Hrvatska enciklopedija, dostupno na: http://www.enciklopedija.hr/natuknica. aspx?id=19372 (20.07.2019.).

26 Akrap, A. i Čipin, I., Usklađivanje poslovnoga i obiteljskoga života u Hrvatskoj: utjecaj na fertilitet, Društvena istraživanja, vol. 20, 1/2011, str. 48-49. 
modelom od ključne su važnosti prilikom ocjene veze između stope fertiliteta i stope participacije žena na tržištu rada. “27

Posljedično tomu, položaj žena na tržištu rada, rizik od nezaposlenosti i stope fertiliteta koje su relativno niske karakteristične su za zemlje kao što su RH i zemlje južne Europe, za razliku od skandinavskih zemalja u kojima je stopa fertiliteta relativno visoka i položaj žena na tržištu rada daleko bolje pravno i stvarno uređen. Prema podatcima za 2017. stopa fertiliteta u RH iznosila je 1.42, dok je u Švedskoj iznosila 1.85, odnosno u Danskoj 1.79, što je više i od EU prosjeka koji iznosi 1.59 (graf 3.).

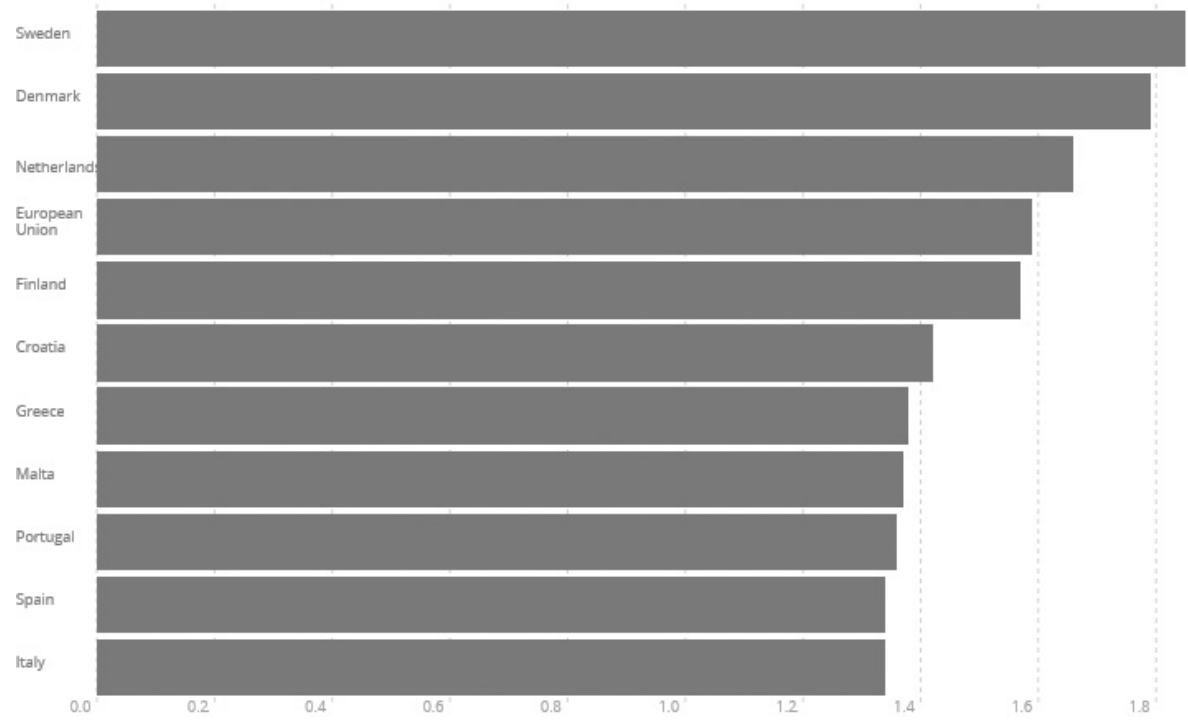

Graf 3. Stopa totalnog fertiliteta 2017. (izvor: Svjetska banka) ${ }^{28}$

Ono što zaposlenim ženama u RH najviše priječi osiguravanje željenoga broja djece jest nedostatak fleksibilnosti na tržištu rada. U RH su poslovi sa skraćenim radnim vremenom rijetki, pa su udane žene prisiljene birati između posla s punim radnim vremenom ili ostati kod kuće kao kućanice. Navedeno nije nimalo poticajno okruženje za rađanje i podizanje djece. Istraživanja pokazuju da je rad sa skraćenim radnim vremenom važan resurs pri usklađivanju poslovnih aktivnosti i obiteljskog života. ${ }^{29}$ Rad sa skraćenim radnim vremenom upravo je ono što bi u RH moglo smanjiti dvostruki teret koji se stavlja na zaposlenu ženu. Dobar je primjer Nizozemska ,gdje uz zajedničku suradnju vlade, poslodavaca i sindikata postoje poslovi sa skraćenim radnim vremenom koji omogućuju stvaranje karijere kao normalan posao s punim

27 ibid., str. 50.

28 The World Bank Group, Fertility rate, total (births per woman), dostupno na: https://data. worldbank.org/indicator/SP.DYN.TFRT.IN?end=2017\&locations=EU-HR-FI-NL-SE-DKGR-IT-MT-PT-ES\&name_desc=false\&start=2017\&view=bar (20.07.2019.).

29 Akrap, A. i Čipin, I., op. cit., str. 52. 
radnim vremenom.“30 Osim toga, uz Dansku, ${ }^{31}$ Nizozemska ${ }^{32}$ je dobar primjer uvođenja modela ne samo fleksibilizacije radnih odnosa, već $\mathrm{i}$ koncepta fleksigurnosti ${ }^{33}$ radnih odnosa koji upravo u ovo području može uvelike pomoći. Iako su politike usklađivanja profesionalnog i obiteljskog života postale važan dio politika država članica EU-a, načini na koji ih zemlje provode su različiti, što dovodi do različitog učinka na položaj roditelja na tržištu rada. U posebice nepovoljnom položaju su žene, čije su stope aktivnosti u najranijoj djetetovoj dobi u većini zemalja bitno niže od stopa aktivnosti muškaraca, a izražen je rodni jaz u plaćama te horizontalna i vertikalna segregacija na tržištu rada uz vidljive varijacije među zemljama. ${ }^{34}$ Naime, u zemljama gdje je veća ponuda poslova sa skraćenim radnim vremenom, u pravilu je i veća stopa zaposlenosti žena, osim u Nizozemskoj, gdje je takav oblik rada toliko rasprostranjen da je čak i metoda pripreme za odlazak u mirovinu. ${ }^{35}$ Najviše žena koje rade sa skraćenim radnim vremenom nalazimo u skandinavskim zemljama, a koje su poznate i po visokoj fleksibilnosti tržišta rada, posebice za žene s malom djecom. Jedan je od razloga visoke stope zaposlenosti ženskoga stanovništva u skandinavskim zemljama upravo široka dostupnost poslova sa skraćenim radnim vremenom. ${ }^{36}$

30 ibid., str. 51.

31 Knudsen, H. i Lind, J., Danish Flexicurity: Not the Same Today as Yesterday, str. 197-211, u: Transnational, European, and National Labour Relations: Flexicurity and New Economy, G. G. Sander, V. Tomljenović, N. Bodiroga-Vukobrat (ur.), Cham, Springer, 2018.

32 Pennings, F., Dilemmas in Organising the Labour Market, Experiences with Flexicurity in the Netherlands, str. 213-222, u: Transnational, European, and National Labour Relations: Flexicurity and New Economy, op. cit.

33 O konceptu fleksigurnosti vidjeti detaljnije: Uspostavni istraživački projekt Hrvatske zaklade za znanost: Fleksigurnost i novi oblici rada (izazovi modernizacije hrvatskog radnog prava) UIP-2014-09-9377. dostupno na: www.pravri.uniri.hr/fleksinora.

34 Dobrotić, I., Politike usklađivanja obiteljskih obaveza i plaćenog rada i položaj roditelja na tržištu rada, Revija za socijalnu politiku, vol. 22, 3/2015., str. 366.

35 Dajak, L. i Orešković, S., Nedostatno korištenje ekonomskih potencijala demografskog starenja u Hrvatskoj, Revija za socijalnu politiku, vol. 25, 1/2018., str. 101.

36 Akrap, A. i Čipin, I., op. cit., str. 51. 


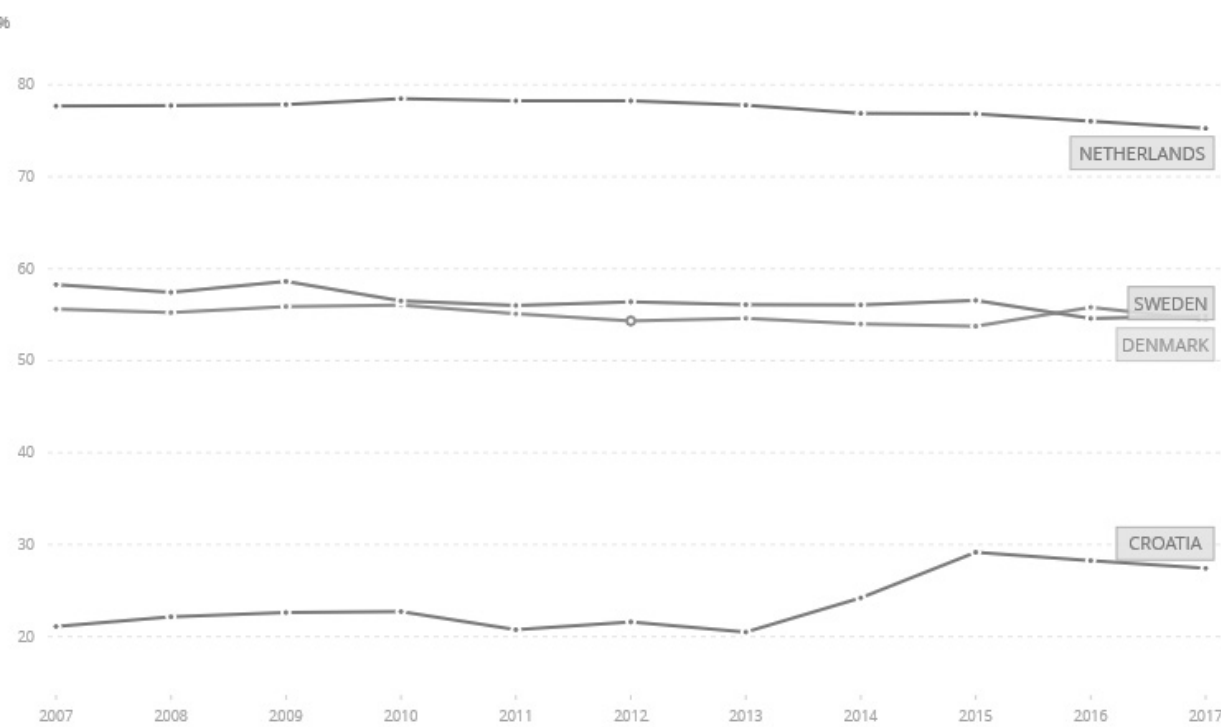

Graf 4. Žene koje rade poslove sa skraćenim radnim vremenom (postotak od ukupnog broja zaposlenih žena) 2007.-2017. (izvor: Svjetska banka) ${ }^{37}$

Iz navedenog slijedi da su se skandinavske zemlje i Nizozemska vrlo dobro organizirale u pomoći ženama u usklađivanju profesionalnog i obiteljskog života te posljedično tome imaju s jedne strane visoki udio zaposlenosti žena i zaposlenosti žena u skraćenom radnom remenu u odnosu na ukupnu zaposlenost žena (Nizozemska (75.26 \%), Švedska (54.85\%), Danska (54.44 \%), a s druge strane najviše stope fertiliteta u EU i kao takve bi mogle biti primjer i ostalim zemljama koje žele postići te ciljeve i biti uspješnije u pomoći ženama u usklađivanju profesionalnog i obiteljskog života. Ipak, rad sa skraćenim radnim vremenom kao rješenje usklađivanja profesionalnog i obiteljskog života ima i svoj negativan učinak, posebno u zemljama poput RH. Naime, time se još dodatno ,doprinosi održavanju tradicionalnih uloga u obitelji, budući da je dominantno koriste žene iako se ta mogućnost u pravilu promovira u neutralnim terminima, ona zapravo povlači za sobom „sekundarnu“ ulogu žena na tržištu rada. Istraživanja pokazuju da rad u nepunom radnom vremenu nosi sa sobom negativne implikacije kao što su niži položaj na tržištu rada, niže plaće, te posljedično niže mirovine jednoga dana“. ${ }^{88}$ Upravo je zbog toga nužno poticati i promovirati ravnopravnost muškaraca i žena.

Pitanjem ravnopravnosti žena i muškaraca intenzivno se bavi i EU koji bilježi povećanje financijskih ulaganja u području nediskriminacije i jednakosti. „Za 2018. godinu u okviru mjere Promicanje nediskriminacije i jednakosti na raspolaganju su odobrena sredstva za preuzimanje obveza u iznosu od 35,8 milijuna EUR-a, što je

37 The World Bank Group, Part time employment, female ( $\%$ of total female employment), dostupno na: https://data.worldbank.org/indicator/SL.TLF.PART.FE.ZS?end=2017\&locations=HR-DKNL-SE\&start=2007\&view=chart (20.07.2019.).

Dobrotić, I., op. cit., str. 366. 
povećanje u izdvajanjima u odnosu na 2015.-2017. i zapravo znači da se ostvaruje napredak u provedbi tog programa." 39 Također Europska komisija objavila je 2015. dokument Strateško djelovanje za rodnu jednakost za razdoblje 2016.-2019. „Strategija je usmjerena na sljedećih pet prioritetnih područja: povećanje sudjelovanja žena na tržištu rada i jednaka ekonomska neovisnost; smanjenje rodno uvjetovanih razlika u plaćama, zaradi i mirovinama i time borba protiv siromaštva među ženama; promicanje ravnopravnosti žena i muškaraca u donošenju odluka; borba protiv rodno uvjetovanog nasilja, zaštita žrtava i pružanje potpore žrtvama te promicanje rodne jednakosti i prava žena diljem svijeta. ${ }^{* 40}$

Kada fokus stavimo na $\mathrm{RH}$ u tom pogledu prema Izvješćc o radu Pravobraniteljice za ravnopravnost spolova za 2017., RH bi trebala uložiti dodatne napore kako bi se stvorili povoljniji uvjeti za usklađivanje profesionalnog i obiteljskog života. „Pregledom stope radne aktivnosti i dalje se uočava trend više stope radne aktivnosti muškaraca nego žena u svim dobnim skupinama od 15 do $65+$ godina života s time da se najveće razlike nalaze u dobnoj skupini od 15 do 24 godine te $\mathrm{u}$ dobnoj skupini od 40 do 64 godina.“41 „Kao razlog Pravobraniteljica navodi upravo tradicionalnu podjelu uloga u obitelji koja je ukorijenjena u hrvatsko društvo, što je potvrđeno istraživanjem, ${ }^{42}$ a zbog koje nezanemariv broj žena napušta tržište rada radi brige o djeci, ali i o starijim i nemoćnim članovima/icama obitelji.“43 Navedenim istraživanjem koje je provedeno 2017. na uzorku od 600 zaposlenih žena različitoga stupnja obrazovanja i zastupljenosti iz svih regija RH utvrđeno je da žene doista provode puno više vremena u brizi za kućanstvo (graf 5.) i djecu (graf 6.) u odnosu na muškarce.

39 Europski parlament, Ravnopravnost muškaraca i žena, dostupno na: http://www.europarl. europa.eu/factsheets/hr/sheet/59/jednakost-muskaraca-i-zena (20.07.2019.).

40 loc. cit.

41 Izvješće o radu Pravobraniteljice za ravnopravnost spolova za 2017. godinu, dostupno na: http:// www.prs.hr/attachments/article/2404/IZVJEŠĆE_O_RADU_ZA_2017.pdf (23.07.2019.), str. 19.

42 Klasić, K., Utjecaj rodne podjele obiteljskih obveza i kućanskih poslova na profesionalni život zaposlenih žena, Zagreb, Pravobranitelj/ica za ravnopravnost spolova Republike Hrvatske, 2017., dostupno na: http://rec.prs.hr/wp-content/uploads/2018/01/Brosura_prijelom_finalno_ web.pdf (28.07.2019.).

43 Izvješće o radu Pravobraniteljice za ravnopravnost spolova za 2017. godinu, op. cit., str. 19. 


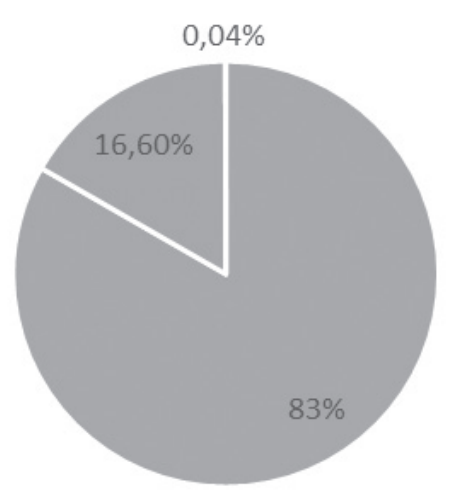

- Sve ili većinu radi žena

- Partneri ravnopravno dijele poslove

- Sve ili većinu radi suprug (partner)

Graf 5. Obavljanje rutinskih kućanskih poslova $(\mathrm{N}=600)$ (izvor: Klasnić, op. cit. 2017. $)^{44}$

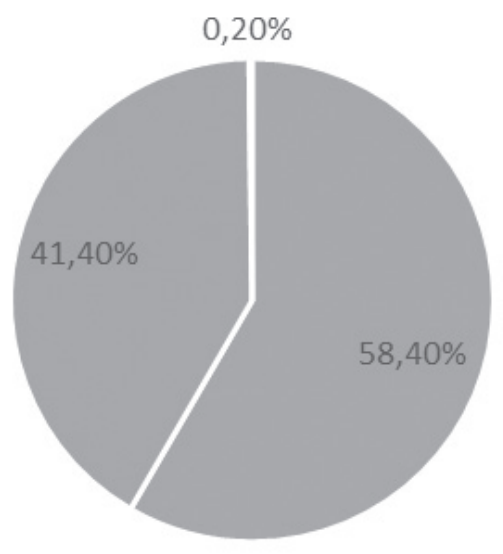

- Sve ili većinu radi žena

- Partneri ravnopravno dijele poslove

- Sve ili većinu radi suprug (partner)

Graf 6. Obavljanje poslova vezanih za brigu o djeci $(\mathrm{N}=503)$ (izvor: Klasnić, op. cit. 2017. $)^{45}$

Takva neravnopravna rodna podjela obiteljskih obaveza i kućanskih poslova za mnoge zaposlene žene ima negativne posljedice i na njihov privatni i na njihov profesionalni život. ${ }^{46}$ Kao rješenje predlaže se poticanje muškaraca na brigu o djeci, većeg sudjelovanja u svim obiteljskim obvezama i kućanskim poslovima te osiguravanje dostupnosti dječjih vrtića i domova za starije i nemoćne članove obitelji te uvođenje fleksibilnog radnog vremena koje poslodavci u RH uglavnom ne prihvaćaju zbog stajališta da će posljedica takvog radnog vremena biti smanjenje radnog učinka radnika/ce. Vezano za poticanje očeva da više sudjeluju u brizi za djecu

44 Klasić, K., op. cit., str. 24.

45 ibid., str. 32.

46 Izvješće o radu Pravobraniteljice za ravnopravnost spolova za 2017. godinu, op. cit., str. 64. 
i da koriste roditeljski dopust, Direktiva Vijeća 2010/18/EU o roditeljskom dopustu ${ }^{47}$ propisuje da svi zaposleni roditelji imaju pravo na četiri mjeseca dopusta nakon rođenja djeteta. S direktivom je usklađen i naš Zakon o rodiljnim i roditeljskim potporama $(\mathrm{u}$ daljnjem tekstu: ZRRP) ${ }^{48}$ prema kojem roditeljski dopust traje šest mjeseci ako ga koristi jedan roditelj, odnosno osam ako ga koriste oba roditelja. Dakle, produžuje se vrijeme trajanja dopusta ako se oba roditelja uključe u brigu za dijete. Ipak, u RH očevi još uvijek premalo koriste prava iz ZRRP-a, što je vidljivo i iz statističkih podataka Hrvatskog zavoda za zdravstveno osiguranje (tablica 4.), što nas svrstava među države EU-a u kojoj očevi najmanje koriste navedene potpore.

Tablica 4. Statistički pokazatelji o korisnicima rodiljnih i roditeljskih potpora u 2017. (izvor: Izvješće o radu Pravobraniteljice za ravnopravnost spolova za 2017. godinu) ${ }^{49}$

\begin{tabular}{|c|c|c|c|c|c|c|c|c|c|}
\hline \multicolumn{2}{|c|}{$\begin{array}{c}\text { RODILJNI DOPUST } \\
\text { DO } 6 \text { MJESECI } \\
\text { STAROSTI } \\
\text { DJETETA }\end{array}$} & \multicolumn{2}{|c|}{$\begin{array}{c}\text { RODITELJSKI } \\
\text { DOPUST NAKON } \\
6 \text { MJESECI } \\
\text { STAROSTI } \\
\text { DJETETA }\end{array}$} & \multicolumn{2}{|c|}{$\begin{array}{l}\text { DOPUST ZA NJEGU } \\
\text { DJETETA S TEŽIM } \\
\text { SMETNJAMA U } \\
\text { RAZVOJU }\end{array}$} & \multicolumn{2}{|c|}{$\begin{array}{c}\text { SKRAĆENO } \\
\text { RADNO VRIJEME } \\
\text { DO 8. G. DJETETA } \\
\text { S TEŽIM } \\
\text { SMETNJAMA U } \\
\text { RAZVOJU }\end{array}$} & \multicolumn{2}{|c|}{$\begin{array}{c}\text { SKRAĆENO } \\
\text { RADNO VRIJEME } \\
\text { OD 8. DO 18. G. } \\
\text { DJETETA S TEŽIM } \\
\text { SMETNJAMA U } \\
\text { RAZVOJU }\end{array}$} \\
\hline \multicolumn{2}{|c|}{ UKUPNO - 65.695} & \multicolumn{2}{|c|}{ UKUPNO - 45.006} & \multicolumn{2}{|c|}{ UKUPNO - 4.803} & \multicolumn{2}{|c|}{ UKUPNO - 1.267} & \multicolumn{2}{|c|}{ UKUPNO - 2.553} \\
\hline $\mathbf{M}$ & $\check{\mathbf{Z}}$ & $\mathbf{M}$ & $\check{\mathbf{Z}}$ & $\mathbf{M}$ & $\check{\mathbf{Z}}$ & $\mathbf{M}$ & $\check{\mathbf{Z}}$ & $\mathbf{M}$ & $\check{\mathbf{Z}}$ \\
\hline $\begin{array}{r}204 \text { ili } \\
0,31 \% \\
\end{array}$ & $\begin{array}{c}65.491 \mathrm{ili} \\
99,69 \% \\
\end{array}$ & $\begin{array}{c}2.013 \mathrm{ili} \\
\underline{4,47 \%} \\
\end{array}$ & $\begin{array}{c}42.993 \text { ili } \\
95.52 \% \\
\end{array}$ & $\begin{array}{l}235 \text { ili } \\
4,89 \%\end{array}$ & $\begin{array}{l}4.568 \mathrm{ili} \\
95,10 \% \\
\end{array}$ & $\begin{array}{l}116 \text { ili } \\
9,15 \%\end{array}$ & $\begin{array}{l}1.151 \mathrm{ili} \\
90,84 \% \\
\end{array}$ & $\begin{array}{l}253 \text { ili } \\
9,90 \%\end{array}$ & $\begin{array}{c}2.300 \text { ili } \\
90,09 \\
\%\end{array}$ \\
\hline \multicolumn{2}{|c|}{$\begin{array}{l}\text { RODILJNA } \\
\text { POŠTEDA }\end{array}$} & \multicolumn{2}{|c|}{$\begin{array}{c}\text { RODITELJSKA } \\
\text { POŠTEDA }\end{array}$} & \multicolumn{2}{|c|}{ RODILJNA BRIGA } & \multicolumn{2}{|c|}{$\begin{array}{c}\text { RODITELJSKA } \\
\text { BRIGA }\end{array}$} & \multicolumn{2}{|c|}{$\begin{array}{l}\text { STANKA ZA } \\
\text { DOJENJE }\end{array}$} \\
\hline \multicolumn{2}{|c|}{ UKUPNO - 7.778} & \multicolumn{2}{|c|}{ UKUPNO - 13.044} & \multicolumn{2}{|c|}{ UKUPNO - 8.978} & \multicolumn{2}{|c|}{ UKUPNO- 11.815} & \multicolumn{2}{|c|}{ UKUPNO-145 } \\
\hline M & $\check{\mathbf{Z}}$ & $\mathbf{M}$ & $\check{\mathbf{Z}}$ & $\mathbf{M}$ & $\check{\mathbf{Z}}$ & $\mathbf{M}$ & Ž & $\mathbf{M}$ & Ž \\
\hline - & $\begin{array}{l}7.778 \text { ili } \\
100 \%\end{array}$ & $\begin{array}{c}42 \text { ili } \\
0,32 \%\end{array}$ & $\begin{array}{l}13.002 \text { ili } \\
99,67 \%\end{array}$ & $\begin{array}{c}13 \mathrm{ili} \\
0,14 \%\end{array}$ & $\begin{array}{l}8.965 \text { ili } \\
99,85 \%\end{array}$ & $\begin{array}{c}66 \text { ili } \\
0,55 \%\end{array}$ & $\begin{array}{l}11.749 \text { ili } \\
99,44 \%\end{array}$ & - & $\begin{array}{l}145 \mathrm{ili} \\
100 \%\end{array}$ \\
\hline
\end{tabular}

Izvješće o radu Pravobraniteljice za ravnopravnost spolova za 2018. doneseno je u ožujku 2019. i u odnosu na 2017. godinu općenito ne sadrži veće promjene. Međutim, vezano za korištenje roditeljskog dopusta muškaraca, došlo je do znatnoga porasta broja korisnika u odnosu na 2017., i to s 2.013 u 2017. na 3.488 korisnika u 2018., što je za 1.475 korisnika $(73,27 \%$ ) više u odnosu na 2017. Kada usporedimo s brojem žena, vidljiv je porast muških korisnika roditeljskog dopusta s 4,47 \% u 2017. na $7,55 \%$ u $2018 .^{50}$ (tablica 5.)

47 Direktiva Vijeća 2010/18/EU od 8. ožujka 2010. o provedbi revidiranog Okvirnog sporazuma o roditeljskom dopustu koji su sklopili BUSINESSEUROPE, UEAPME, CEEP $i$ ETUC te o stavljanju izvan snage Direktive 96/34/EZ, SL L 68/13, 18.03.2010. Vidi detaljnije izmjene, infra.

48 Zakon o rodiljnim i roditeljskim potporama, Narodne novine, br. 85/08., 110/08., 34/11., 54/13., 152/14. i 59/17. - u daljnjem tekstu: ZRRP).

49 Izvješće o radu Pravobraniteljice za ravnopravnost spolova za 2017. godinu, op. cit., str. 70.

50 Izvješće o radu Pravobraniteljice za ravnopravnost spolova za 2018. godinu, dostupno na: http://www.prs.hr/attachments/article/2645/Izvješće\%20o\%20radu\%20Pravobraniteljice $\% 20$ 
Tablica 5. Statistički pokazatelji o korisnicima rodiljnih i roditeljskih potpora u 2018. (izvor: Izvješće o radu Pravobraniteljice za ravnopravnost spolova za 2018. godinu $)^{51}$

\begin{tabular}{|c|c|c|c|c|c|c|c|c|c|}
\hline \multicolumn{2}{|c|}{$\begin{array}{l}\text { RODILJNI DOPUST } \\
\text { DO } 6 \text { MJESECI } \\
\text { STAROSTI } \\
\text { DJETETA }^{97}\end{array}$} & \multicolumn{2}{|c|}{$\begin{array}{c}\text { RODITELJSKI } \\
\text { DOPUST NAKON } \\
6 \text { MJESECI } \\
\text { STAROSTI } \\
\text { DJETETA }\end{array}$} & \multicolumn{2}{|c|}{$\begin{array}{c}\text { DOPUST ZA NJEGU } \\
\text { DJETETA S TEŽIM } \\
\text { SMETNJAMA U } \\
\text { RAZVOJU }\end{array}$} & \multicolumn{2}{|c|}{$\begin{array}{c}\text { SKRAĆENO } \\
\text { RADNO VRIJEME } \\
\text { DO 8. G. DJETETA } \\
\text { S TEŽIM } \\
\text { SMETNJAMA U } \\
\text { RAZVOJU } \\
\end{array}$} & \multicolumn{2}{|c|}{$\begin{array}{c}\text { SKRAĆENO } \\
\text { RADNO VRIJEME } \\
\text { OD 8. DO 18. G. } \\
\text { DJETETA S TEŽIM } \\
\text { SMETNJAMA U } \\
\text { RAZVOJU }\end{array}$} \\
\hline \multicolumn{2}{|c|}{ UKUPNO - $68.146^{98}$} & \multicolumn{2}{|c|}{ UKUPNO -46.16099} & \multicolumn{2}{|c|}{ UKUPNO - $4.979{ }^{100}$} & \multicolumn{2}{|c|}{ UKUPNO - $1.553^{101}$} & \multicolumn{2}{|c|}{ UKUPNO - 2.798} \\
\hline M & $\check{\mathbf{Z}}$ & M & $\check{\mathbf{Z}}$ & M & $\check{\mathbf{Z}}$ & M & $\check{\mathbf{Z}}$ & M & $\check{\mathbf{Z}}$ \\
\hline $\begin{array}{l}197 \mathrm{ili} \\
0,28 \% \\
\end{array}$ & $\begin{array}{c}67.949 \text { ili } \\
99,71 \% \\
\end{array}$ & $\begin{array}{c}3.488 \\
\mathrm{Ili} \\
7,55 \% \\
\end{array}$ & $\begin{array}{c}42.672 \text { ili } \\
92,44 \% \\
\end{array}$ & $\begin{array}{l}226 \mathrm{ili} \\
4,53 \% \\
\end{array}$ & $\begin{array}{l}4.753 \mathrm{ili} \\
95,46 \% \\
\end{array}$ & $\begin{array}{r}168 \mathrm{ili} \\
10,81 \% \\
\end{array}$ & $\begin{array}{l}1.385 \mathrm{ili} \\
89,18 \% \\
\end{array}$ & $\begin{array}{c}276 \\
\text { ili } 9,86 \%\end{array}$ & $\begin{array}{l}2.552 \mathrm{ili} \\
90,13 \% \\
\end{array}$ \\
\hline \multicolumn{2}{|c|}{$\begin{array}{l}\text { RODILJNA } \\
\text { POŠTEDA }\end{array}$} & \multicolumn{2}{|c|}{$\begin{array}{l}\text { RODITELJSKA } \\
\text { POŠTEDA }\end{array}$} & \multicolumn{2}{|c|}{ RODILJNA BRIGA } & \multicolumn{2}{|c|}{$\begin{array}{c}\text { RODITELJSKA } \\
\text { BRIGA }\end{array}$} & \multicolumn{2}{|c|}{$\begin{array}{l}\text { STANKA ZA } \\
\text { DOJENJE }\end{array}$} \\
\hline \multicolumn{2}{|c|}{ UKUPNO - 6.425} & \multicolumn{2}{|c|}{ UKUPNO - 11.026} & \multicolumn{2}{|c|}{ UKUPNO - 9.199} & \multicolumn{2}{|c|}{ UKUPNO- 12.448} & \multicolumn{2}{|c|}{ UKUPNO-109 ${ }^{102}$} \\
\hline M & $\mathbf{Z}$ & M & Ž & $\mathbf{M}$ & Ž & M & Ž & M & Ž \\
\hline $\begin{array}{c}4 \text { ili } \\
0,06 \%\end{array}$ & $\begin{array}{l}6.428 \text { ili } \\
99,93 \%\end{array}$ & $\begin{array}{l}43 \text { ili } \\
0,39 \%\end{array}$ & $\begin{array}{c}10.983 \text { ili } \\
99,61 \%\end{array}$ & $\begin{array}{l}10 \text { ili } \\
0,10 \%\end{array}$ & $\begin{array}{l}9.189 \text { ili } \\
99,89 \%\end{array}$ & $\begin{array}{c}66 \text { ili } \\
0,53 \%\end{array}$ & $\begin{array}{c}12.382 \text { ili } \\
99,46 \%\end{array}$ & - & $\begin{array}{l}109 \mathrm{ili} \\
100 \%\end{array}$ \\
\hline
\end{tabular}

„Vezano uz radno okruženje, pokazuje kako očevi u RH od razloga nekorištenja roditeljskog dopusta ističu upravo strah od mogućeg gubitka posla te problema $\mathrm{u}$ karijeri, ali i nerazumijevanje poslodavaca te onemogućivanje korištenja prava. ${ }^{\text {"52 }}$ Osim toga, bojazan je i visina naknade tijekom korištenja roditeljskog dopusta koje su još uvijek relativno niske unatoč tomu što su se povećale zadnjim zakonskim izmjenama. Naime, do stupanja na snagu izmjena i dopuna ZRRP-a (na snazi od 1. srpnja 2017.) naknada je mogla iznositi najviše $80 \%$ proračunske osnovice $(2.660,80$ kn), a sada navedeno iznosi najviše $120 \%$ proračunske osnovice $(3.991,20 \mathrm{kn})$. Ako usporedimo taj iznos s prosječnom neto plaćom u RH koja je prema podatcima Državnog zavoda za statistiku u travnju 2019. godine iznosila $6.434,00 \mathrm{kn},{ }^{53}$ dolazimo do zaključka da naknada iznosi svega $62 \%$ prosječne hrvatske plaće, što nikako nije poticajno.

Problem koji se dalje javlja, a koji pravobraniteljica također ističe je i činjenica da se žene teže zapošljavaju nego muškarci u svim skupinama i na svim razinama obrazovanja (iako se žene s visokim obrazovanjem zapošljavaju brže od onih s nižim stupnjem obrazovanja) te da statistički zarađuju manje od muškaraca. Prema izvješću iz 2017. „muškarci u prosjeku na godišnjoj razini zarade 11.412 kn više nego žene,

za\%20ravnopravnost\%20spolova\%20za\%202018.\%20godinu_〜.pdf (23.07.2019.), str. 62.

51 ibid., str. 61.

52 Dobrotić, I. i Varga, M., Zašto su važni očevi dopusti i kvote? Komparativni pregled shema dopusta za očeve u europskim zemljama te čimbenika i učinaka njihova korištenja, Revija za sociologiju, vol. 48, 2/2018, str. 229.

53 Državni zavod za statistiku, Prosječne mjesečne neto i bruto plaće zaposlenih za travanj 2019., dostupno na: https://www.dzs.hr/Hrv_Eng/publication/2019/09-01-01_04_2019.htm (30.08.2019.). 
odnosno zarade 1.47 prosječne hrvatske bruto-plaće više“. ${ }^{54}$ Prema izvješću iz 2018. stanje se dodatno pogoršalo te „,muškarci u prosjeku na godišnjoj razini zarade 13.572 kn više nego žene, odnosno da zarade 1.68 prosječne hrvatske bruto plaće više. Ova se brojka tako sve više približava prosjeku od dvije prosječne bruto plaće više na godišnjoj razini u korist muškaraca" ${ }^{55}$ Razlog tomu je što su žene zastupljenije na hijerarhijski nižim položajima, a samim time i manje plaćene. U usporedbi s europskim prosjekom koji iznosi $16.2 \%$, jaz u plaćama u RH s $13.19 \%$ je manji, no on je opasan jer za razliku od EU28 gdje je trend pada jaza u plaćama, u RH on još od 2010. stalno i odlučno raste. ${ }^{56}$ To znači da se žene i nadalje nalaze u raskoraku između tržišta rada i zahtjeva patrijarhalnoga društvenog okruženja, što ih stalno drži u podređenom društvenom položaju. Iskustva govore da roditeljski dopust u pravilu koristi onaj član obitelji čija su primanja manja, kako se ne bi ugrozila financijska snaga obitelji, a to su nažalost pretežno žene u RH. ${ }^{57}$

Iz svega navedenog vidljivo je da na mogućnost usklađivanja profesionalnog i obiteljskog života utječu mnogi čimbenici koji se međusobno isprepliću. S obzirom na navedene podatke o zaista malom korištenju prava očeva prema ZRRP-u, jedno do mogućih rješenja koje predlaže i pravobraniteljica je uvođenje obveznog očevog dopusta. Najšire gledano, u europskim zemljama prevladavaju dva glavna argumenta iza reformi kojima se očevima osigurava veći pristup pravima na dopuste - rodna ravnopravnost i dobrobit djeteta. Uvođenje se očevih dopusta i kvota, stoga vidi bitnim instrumentima koji bi trebali ojačati položaj žena na tržištu rada, ali i pridonijeti povećanom angažmanu muškaraca u privatnoj sferi. Zemlje koje su prve uvele dopuste za očeve, a to su nordijske zemlje posebno ističu dobrobit djeteta kao razlog uvođenja takvih dopusta. U Švedskoj se tako ističe pravo djeteta i na očevu brigu, navodeći kako bi dijete, da može, odabralo provoditi više vremena s ocem. Ti argumenti, koji su tipični i za druge nordijske zemlje, ponajprije polaze od spoznaje da rana aktivna uključenost očeva u brigu o djetetu pozitivno utječe na djetetov razvoj. Konkretnije, doprinosi kognitivnom i društvenom razvoju djeteta, razvijenijoj empatiji, višem stupnju samopoštovanja, boljim rezultatima u školi te manje izraženim rodno stereotipnim uvjerenjima. ${ }^{58}$ Veliki broj europskih zemalja ima uveden dopust za očeve i to uglavnom u kraćem trajanju, do dva tjedna, ali ima i zemalja koje su uvele puno duži dopust, npr. Finska (devet tjedana), Portugal (pet tjedana, obvezatni dio 15 dana koji se mora iskoristiti u prvih mjesec dana života djeteta), Španjolska, Litva i Slovenija (četiri tjedna) (graf 7.).

54 Izvješće o radu Pravobraniteljice za ravnopravnost spolova za 2017. godinu, op. cit., str. 25.

55 Izvješće o radu Pravobraniteljice za ravnopravnost spolova za 2018. godinu, op. cit., str. 28.

56 loc. cit.

57 ibid., str. 64.

58 Dobrotić, I. i Varga, M., op. cit., str. 212-213. 

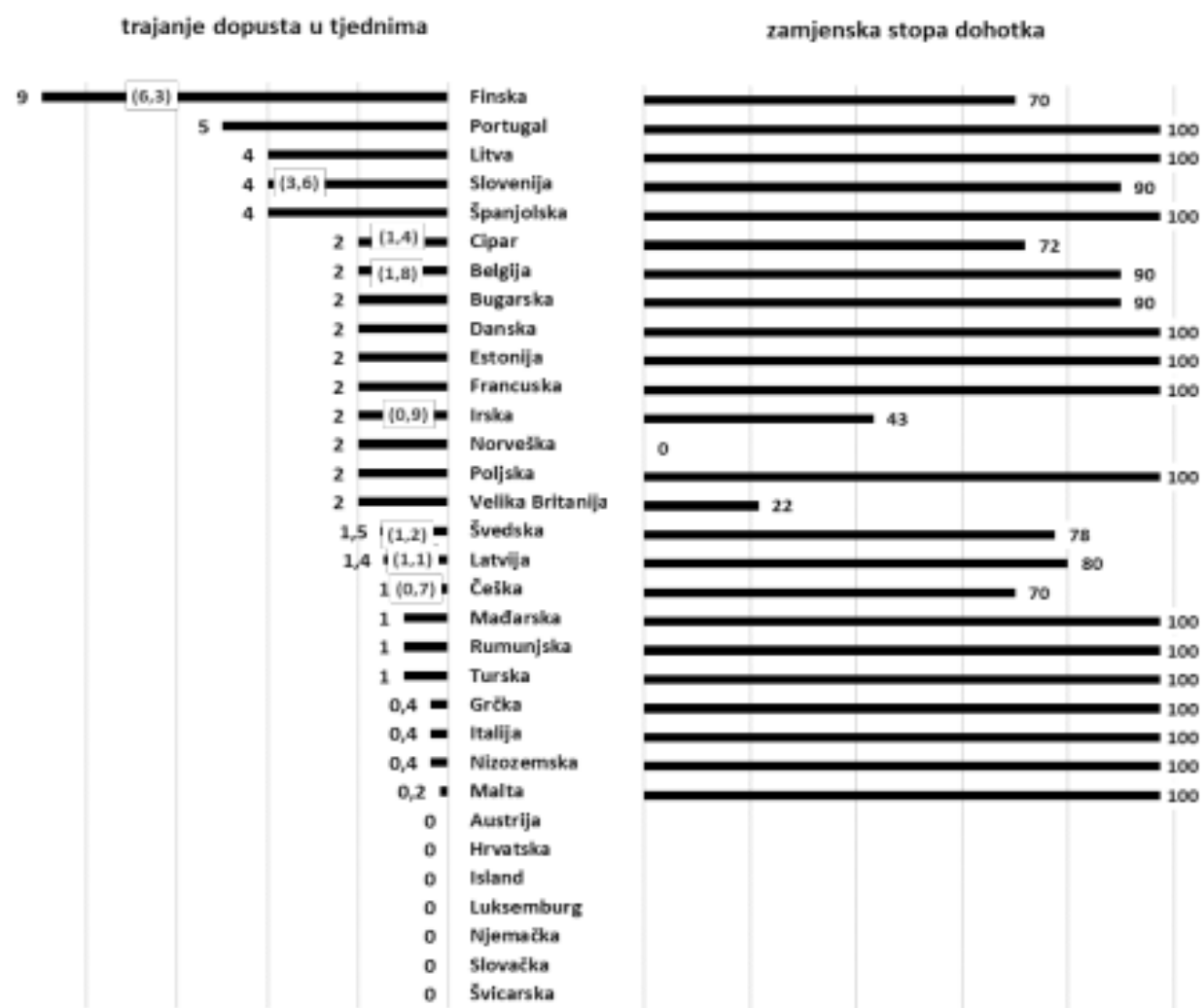

Graf 7. Trajanje dopusta očeva u tjednima i zamjenska stopa dohotka u europskim zemljama u 2017. godini (izvor: Dobrotić, Varga) $)^{59}$

Iz grafa 7. vidljivo je da su dopusti uglavnom dobro plaćeni i iznose od 80 do $100 \%$ prethodno isplaćene plaće. Samo je u nekoliko zemalja naknada bitno niža, čime se, preračunato na puni ekvivalent, znatno smanjuju raspoloživi dani dopusta, ponajprije u Velikoj Britaniji i Irskoj, gdje su naknade paušalne, ali i u Norveškoj, gdje država ne plaća očev dopust. Ipak, u Norveškoj je to pravo pokriveno kolektivnim ugovorima pa je uobičajena praksa da očevi imaju pravo na puni iznos plaće tijekom dva tjedna očeva dopusta. “60

S obzirom na to da ne postoje minimalni standardi za roditeljski dopust očeva na razini EU-a, donesena je nova Direktiva o ravnoteži između poslovnog i privatnog života roditelja $i$ pružatelja skrbi. ${ }^{61}$ Direktivom se utvrđuju minimalni zahtjevi u pogledu dopusta očeva, roditeljskog dopusta i dopusta za pružatelje skrbi, kao i minimalni zahtjevi u pogledu fleksibilnih radnih uvjeta za radnike koji su roditelji

59 ibid., str. 215.

60 ibid., str. 214.

61 Direktiva (EU) 2019/1158 Europskog parlamenta i Vijeća od 20. lipnja 2019. o ravnoteži između poslovnog i privatnog života roditelja i pružatelja skrbi i o stavljanju izvan snage Direktive Vijeća 2010/18/EU, SL L 188/79, 12.07.2019. (u daljnjem tekstu: Direktiva (EU) 2019/1158). 
ili pružatelji skrbi. Olakšavanjem usklađivanja poslovnog i obiteljskog života takvih roditelja i pružatelja skrbi Direktivom bi se trebalo doprinijeti ciljevima iz Ugovora koji se odnose na ostvarivanje ravnopravnosti žena i muškaraca s obzirom na njihove mogućnosti na tržištu rada, jednako postupanje na radnome mjestu i promicanje visoke razine zaposlenosti u EU-u.$^{62}$ Osim prethodno navedenoga, u tekstu se Direktive jasno uočava namjera da se na razini EU-a podigne svijest o važnosti aktiviranja očeva u odgoju djeteta zbog dobrobiti djeteta i poticanja ravnopravnosti žena i muškaraca i u privatnoj sferi. „Kako bi se potaknula ravnopravnija podjela obveza skrbi između žena i muškaraca i omogućilo rano stvaranje emocionalne veze između očeva i djece, trebalo bi uvesti pravo na dopust za očeve ili, ako je i u mjeri u kojoj je to priznato nacionalnim pravom, za ekvivalentne druge roditelje. Takav „očinski“ dopust trebao bi se iskoristiti u vrijeme oko rođenja djeteta i trebao bi biti jasno povezan s rođenjem djeteta u svrhu pružanja skrbi." ${ }^{63}$ Propisano je i minimalno trajanje, a ono iznosi 10 radnih dana. „Države članice poduzimaju potrebne mjere kako bi osigurale da očevi ili, ako je i u mjeri u kojoj je to priznato nacionalnim pravom, ekvivalentni drugi roditelji imaju pravo na „očinski“ dopust u trajanju od 10 radnih dana koji se koristi povodom rođenja radnikova djeteta. Države članice mogu odlučiti o tome može li se „očinski“ dopust djelomično iskoristiti i prije ili samo nakon rođenja djeteta, kao i o tome može li se takav dopust iskoristiti u fleksibilnim oblicima." ${ }^{\text {"64 }}$ Navedena Direktiva tek treba stupiti na snagu, a države članice bit će obvezne provesti ju u svoja nacionalna zakonodavstva do 2022. godine. Stoga tek slijedi vidjeti kako će RH i ostale članice urediti pitanje dopusta očeva i fleksibilnih radnih uvjeta za radnike koji su roditelji ili pružatelji skrbi.

Ono što je još vrlo važno naglasiti, kada govorimo o dopustima za očeve, su i rezultati istraživanja koja „pokazuju da će očevi najčešće koristiti dopuste kad ih same sheme dopusta budu eksplicitno navodile kao korisnike prava (putem „očevih“ dopusta $\mathrm{i} / \mathrm{ili}$ kvota) te kad dopuste budu pratile visoke zamjenske stope dohotka. Rodno neutralne sheme, odnosno roditeljski dopusti koji su u cijelosti prenosivi s jednog roditelja na drugoga, imaju slabiji učinak, pa čak i kad ih prate visoke nadomjesne stope dohotka“". ${ }^{65}$ Primjer je već spomenuta Norveška u kojoj je takve dopuste koristilo samo od 1 do $4 \%$ očeva, da bi nakon uvođenja očevih kvota 1993. udio očeva na dopustima naglo porastao u 2000., čak do $85 \%{ }^{66}$ te se od tada kreće na približno $90 \% .{ }^{67} 68$

62 Direktiva (EU) 2019/1158, toč. 16. preambule.

63 Direktiva (EU) 2019/1158, toč. 19. preambule.

64 Direktiva (EU) 2019/1158, čl. 4. st. 1.

65 Dobrotić, I. i Varga, M., op. cit., str. 219.

66 Brandth, B. i Kvande, E., Fathers and flexible parental leave, Work, employment and society, vol. 30, 2/2016, str. 275-290, prema Dobrotić, I. i Varga, M., op. cit., str. 219.

67 Leave Policy \& Research, International Review of Leave Policies and Research 2017., dostupno na: http://www.leavenetwork.org/lp_and_r_reports/, prema Dobrotić, I. i Varga, M., op. cit., str. 219.

68 Dobrotić, I. i Varga, M., op. cit., str. 219. 


\section{DEMOGRAFSKE PROMJENE}

„Socijalno-demografski procesi u znatnoj mjeri utječu na socijalnu politiku koja podrazumijeva državnu preraspodjelu nacionalnog dohotka usmjerenu na prevladavanje socijalnih rizika, smanjenje socijalnih nejednakosti te ujednačavanje životnih uvjeta građana." ${ }^{69}$ Puljiz izdvaja četiri socijalno-demografska čimbenika koji utječu na socijalnu politiku. „Prvo, radi se o opadanju fertiliteta, odnosno smanjenju stopa biološke reprodukcije stanovništva. Drugo, opadanje fertiliteta povezano je s demografskim starenjem koje podrazumijeva povećanje udjela starijeg stanovništva u ukupnom stanovništvu. Na trećem su mjestu migracije stanovništva, kako unutrašnje, tako i vanjske, koje poprimaju sve veće razmjere. Četvrto je proces transformacija strukture i funkcija obitelji." ${ }^{\text {"70 }} \mathrm{O}$ problemu opadanja fertiliteta bilo je riječi u prethodnom poglavlju, no podsjećamo da je u RH stopa fertiliteta iznosila 1.42 za 2017. (graf 3.). Drugi važan problem, koji je već ranije spomenut, je povećanje udjela starijeg stanovništva u ukupnom stanovništvu (vidi infra, graf 8.).

\subsection{Demografska kretanja u Hrvatskoj}

Popis 1900.

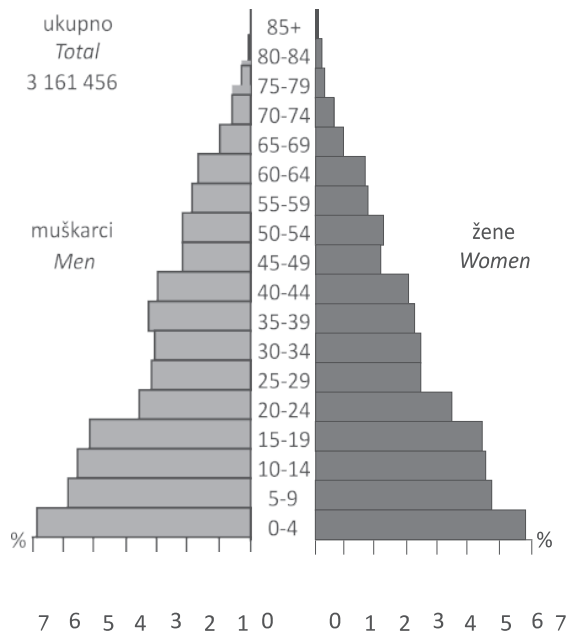

Popis 1953.

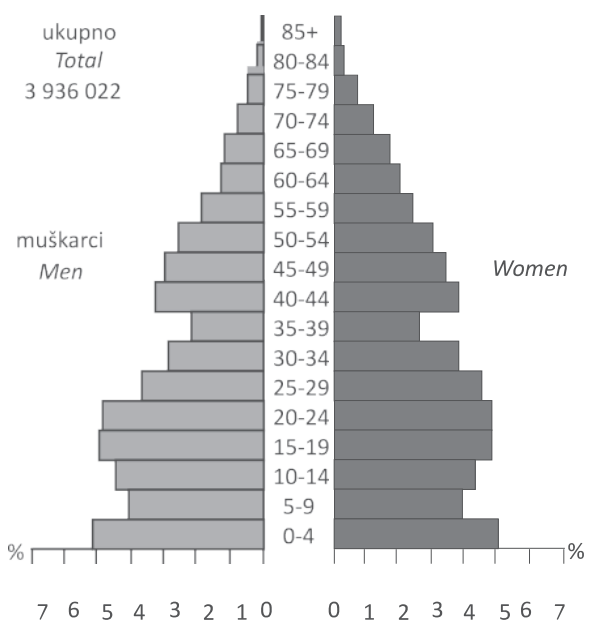

69 Puljiz, V., Starenje stanovništva - izazov socijalne politike, Revija za socijalnu politiku, vol. 23, 1/2016, str. 81-98.

70 ibid., str. 82. 
Popis 2011 .

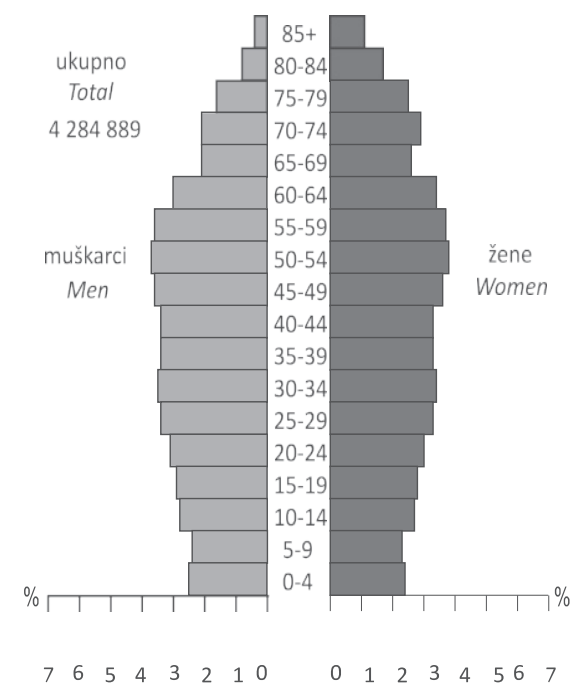

Popis 2051. (projekcija)

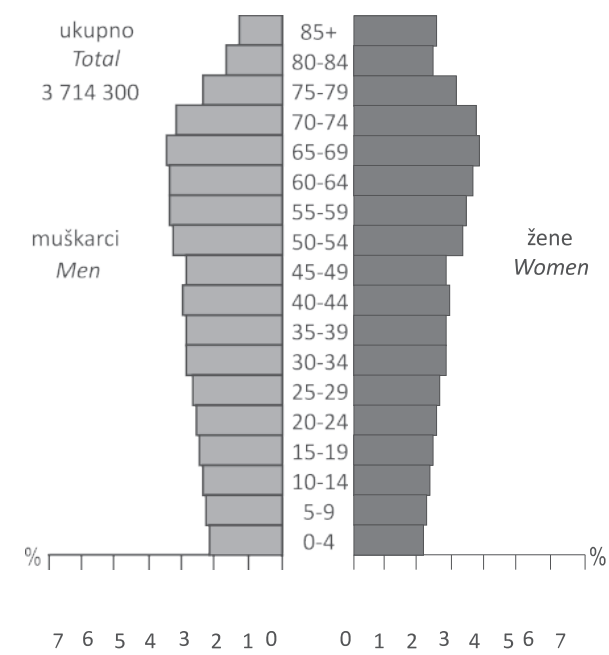

Graf 8. Stanovništvo prema starosti i spolu 1900., 1953., 2011. i 2051. (izvor: DZS) ${ }^{71}$

Kada je riječ o demografskim kretanjima iz grafa 8 . vidljivo je da se početna „piramida“ stanovništva iz 1900-ih i pedesetih godina prošlog stoljeća mijenja, odnosno narušava, vjerojatno zbog posljedica rata. No, u posljednjih nekoliko desetljeća što je vidljivo iz popisa stanovništva iz 2011. i projekcije za 2051. piramida se sve više sužava, odnosno povećava se broj starijega stanovništva, smanjuje se broj mlađe populacije i zapravo se populacija brojčano ujednačava. Tako je u RH udio starijih od 65 godina 2013. dosegao $18 \%$, a projekcije za 2060. godinu govore da će se njihov udjel povećati na oko $30 \%$ ukupnog stanovništva. Zanimljiva je usporedba naše zemlje s EU-om: udio stanovništva starijeg od 65 godina 2013. u EU-u je, kao i u RH, bio $18 \%$, međutim, prema projekcijama za 2060., EU će imati $25 \%$ starijeg stanovništva, dakle, manje nego RH. ${ }^{72}$ Iz navedenog se može zaključiti da problem starenja stanovništva nije samo problem RH, već je to mnogo šira pojava, no u slučaju RH je još izraženija. „Na drugoj strani, povoljniju će demografsku situaciju imati nordijske i anglosaksonske zemlje, čemu uzrok treba tražiti u većim stopama fertiliteta te u specifičnim obiteljskim i populacijskim politikama tih zemalja.“73

Prema podatcima Državnog zavoda za statistiku prosječna starost stanovništva se od 1953. stalno povećava te je 1953. iznosila 31,9 godina za žene i 29,3 godina za muškarce, dok je 2016. iznosila je 44,5 godina za žene i 41 godina za muškarce. ${ }^{74}$ Isto

71 Državni zavod za statistiku Republike Hrvatske, Žene i muškarci u Hrvatskoj 2018., dostupno na: https://www.dzs.hr/Hrv_Eng/menandwomen/men_and_women_2018.pdf (28.07.2019.), str. 8.

72 Puljiz, V., Starenje stanovništva - izazov socijalne politike, op. cit., str. 85.

73 loc. cit.

74 Državni zavod za statistiku Republike Hrvatske, Žene i muškarci u Hrvatskoj 2018., op. cit., str. 11. 
tako, povećava se prosječna starost umrlih osoba koja je 1950. iznosila 45,9 godina za žene i 42 godine za muškarce, 1970. iznosila je 68,1 za žene i 61,6 godina za muškarce, a 2016. iznosila je 79,9 godina za žene i 72,8 godina za muškarce. ${ }^{75}$

Prema iznesenim podatcima može se uočiti da je došlo do znatnoga produljenja trajanja ljudskoga života u posljednjim desetljećima. „Odgovor treba tražiti u znatno višem standardu stanovništva, kao i u podizanju razine zdravstvene zaštite koja je utjecala na poboljšanje zdravlja stanovništva. Podsjetimo da su u europskim zemljama nakon Drugoga svjetskog rata praktično iskorijenjene zarazne bolesti koje su harale još u prvim desetljećima dvadesetog stoljeća." ${ }^{\text {"76 }}$

Daljnji važan čimbenik koji utječe na socijalno-demografske procese su migracije stanovništva koje negativno utječu na gospodarske i socijalne prilike, pogotovo u RH po ulasku u članstvo EU-a, kao i promjena strukture obitelji, povećane stope razvoda, povećan broj jedno-roditeljskih obitelji i samačkih kućanstava (tablice 1. i 2.) o kojima je bilo riječi u dijelu ovoga rada gdje se govorilo o novim socijalnim rizicima.

\subsection{Mjere populacijske politike, odnosno socijalnog ulaganja u Hrvatskoj}

Već je prethodno u ovom radu navedeno kako je populacijska politika usmjerena na demografske promjene, odnosno na povećanje ili smanjenje broja stanovnika te da se u RH kao u EU-27 radi o politikama povećanja broja stanovnika. Kroz mjere obiteljske politike, tj. mjere koje utječu na kvalitetu života obitelji, posebice mladih obitelji, RH nastoji utjecati na demografske promjene pa su mnoge mjere istodobno mjere populacijske i obiteljske politike.

Mjere obiteljske politike mogu biti ako je riječ o prestacijama u novcu kao što su različite naknade za roditelje i majke, porezne povlastice (olakšice), dječji doplatci ili mogu biti vremenske koje se odnose na, primjerice dopuste kao oblik opravdanog odsustva i neobavljanja rada. Danas osim vremenskih i novčanih mjera sve važniju ulogu imaju i različite usluge za obitelji kao što su organizacija i sufinanciranje dječjih vrtića, sufinanciranje dječjih udžbenika, školske prehrane ili prijevoza učenika i druge potpore vezane za školovanje, odnosno obrazovanje i mjere povezane sa stambenim zbrinjavanjem. Navedene usluge za obitelj koje se provode na lokalnoj i županijskoj razini u 2019. objavilo je Ministarstvo za demografiju, obitelj, mlade i socijalnu politiku (u daljnjem tekstu: Ministarstvo) na svojoj službenoj mrežnoj stranici definiravši ih kao demografske mjere, vrlo detaljno za svaku pojedinu županiju, grad i općinu, vidi infra. ${ }^{77}$

Jedna od mjera kojom se nastoji povećati kvaliteta života obitelji i na taj način utjecati na demografske promjene su dječji doplatci, prepoznati kao jedan od

75 ibid., str. 17.

76 Puljiz, V., Starenje stanovništva - izazov socijalne politike, op. cit., str. 83.

77 Ministarstvo za demografiju, obitelj, mlade i socijalnu politiku, Demografske mjere na lokalnoj i županijskoj razini, dostupno na: https://mdomsp.gov.hr/istaknute-teme/demografija/ demografske-mjere-na-lokalnoj-i-zupanijskoj-razini/10177 (25.07.2019.). 
glavnih državnih programa za djecu u $\mathrm{RH},{ }^{78}$ koji se ostvaruju u sklopu nadležnosti Hrvatskog zavoda za mirovinsko osiguranje i temeljem Zakona o doplatku za djecu. ${ }^{79}$ Pravo na doplatak za djecu stječe korisnik uz uvjet da mu ukupni dohodak ostvaren u prethodnoj kalendarskoj godini po članu kućanstva mjesečno ne prelazi $70 \%$ proračunske osnovice (u daljnjem tekstu: dohodovni cenzus) te da živi u kućanstvu s djetetom..$^{80}$ „U Proračunu su utvrđena sredstva za naknade i druga primanja na temelju posebnih propisa. Osnovica za obračun naknada i drugih primanja iznosi 3.326,00 kuna. ${ }^{\text {“81 }}$ Prema tome dohodovni cenzus, odnosno $70 \%$ proračunske osnovice iznosi 2.328,20 kn. Uvjeti i iznosi dječjih doplataka u Republici Hrvatskoj u 2019. prikazani su u tablici 6.

Tablica 6. Uvjeti i iznosi dječjih doplataka 2019. (izvor: HZMO) ${ }^{82}$

\begin{tabular}{|l|l|l|l|}
\hline \multicolumn{1}{|c|}{$\begin{array}{c}\text { Prosječni mjesečni } \\
\text { dohodak po članu } \\
\text { kućanstava (\% } \\
\text { proračunske osnovice) }\end{array}$} & \multicolumn{1}{|c|}{ Iznos u 2019. (kn) } & $\begin{array}{c}\text { Doplatak (\% } \\
\text { proračunske } \\
\text { osnovice) po djetetu }\end{array}$ & Iznos u 2019. (kn) \\
\hline Do 16,33 & 543,14 & 9 & 229,34 \\
\hline Od 16,34 do 33,66 & Od 543,15 do 1 119,53 & 7,5 & 249,45 \\
\hline $\begin{array}{l}\text { Od 33,67 do 70 } \\
\text { Za dijete bez oba roditelja ili za dijete čija su oba } \\
\text { roditelja: } \\
\text { - nepoznata } \\
\text { - nepoznatog prebivališta } \\
\text { - potpuno nesposobni za samostalan život i rad ili } \\
\text { - im je oduzeta poslovna sposobnost }\end{array}$ & 6 & 199,56 \\
\hline $\begin{array}{l}\text { Za dijete s jednim roditeljem ili za dijete čiji je jedan } \\
\text { roditelj: } \\
\text { - nepoznat } \\
\text { - nepoznatog prebivališta } \\
\text { - potpuno nesposoban za samostalan život i rad ili } \\
\text { - mu je oduzeta poslovna sposobnost }\end{array}$ & Iznos utvrđenog doplatka povećava se za $15 \%$. \\
\hline $\begin{array}{l}\text { Za dijete s oštećenjem zdravlja } \\
\text { Iznos utvrđenog doplatka povećava se za 25 \%. }\end{array}$ & Iznos utvrđenog doplatka povećava se za 25\%. $\%$. \\
\hline
\end{tabular}

78 Ajduković, M., Rajter, M., Rezo, I., Obiteljski odnosi i roditeljstvo u obiteljima različitog prihoda: kako je život u visokom riziku od siromaštva povezan s funkcioniranjem obitelji adolescenata, Revija za socijalnu politiku, vol. 26, 1/2018, str. 73 .

79 Zakon o doplatku za djecu, Narodne novine, br. 94/01., 138/06., 107/07., 37/08., 61/11., 112/12., 82/15., 58/18.

80 Zakon o doplatku za djecu, cit., čl. 16.

81 Zakon o izvršavanju Državnog proračuna Republike Hrvatske za 2019. godinu, Narodne novine, br. 113/18., čl. 23.

82 Hrvatski zavod za mirovinsko osiguranje, Cenzusi i stope doplatka, dostupno na: http://www. mirovinsko.hr/default.aspx?id=100\#1 (25.07.2019.). 


\begin{tabular}{|l|l|}
\hline Za djecu s težim ili teškim invaliditetom & $\begin{array}{l}\text { Ostvaruje se neovisno o visini prihoda koji } \\
\text { kućanstvo korisnika ostvaruje, a svota doplatka } \\
\text { za djecu određuje se u visini od 25\% od } \\
\text { proračunske osnovice, odnosno 831,50 kn. }\end{array}$ \\
\hline $\begin{array}{l}\text { Pronatalitetni dodatak (uz utvrđenu svotu doplatka za } \\
\text { djecu) }\end{array}$ & $\begin{array}{l}500,00 \mathrm{kn} \text { ako koristi doplatak za troje djece, } \\
\text { odnosno 1 } 1000,00 \text { kn mjesečno ako koristi } \\
\text { doplatak za četvero i više djece. }\end{array}$ \\
\hline
\end{tabular}

Ono što je još korisno naglasiti je da je 1. srpnja 2018. na snagu stupio Zakon o izmjenama i dopunama Zakona o doplatku za djecu te da je dohodovni cenzus za ostvarivanje prava na doplatak za djecu po članu kućanstva povećan na $70 \%$ proračunske osnovice, umjesto dotadašnjih $50 \%$, dok se iznos proračunske osnovice nije mijenjao od 2002. pa do danas. S obzirom na povećanje troškova života u ovih više od 17 godina, valjalo bi de lege ferenda svakako razmisliti o njegovu povećanju kao nužnost.

Važna su mjera i novčane potpore iz ZRRP-a. Cilj je, odnosno svrha ZRRP-a da se tim zakonom radi zaštite majčinstva (materinstva), njege novorođenog djeteta i njegova podizanja te usklađivanja obiteljskog i poslovnog života propisuje pravo roditelja i njemu izjednačene osobe koja se brine o djetetu na vremenske i novčane potpore, uvjeti i način njihova ostvarivanja i financiranja te tijela nadležna za provedbu toga Zakona ${ }^{83} \mathrm{U}$ vremenske se potpore ubrajaju dopusti, poštede od rada i propisano vrijeme za brigu o djetetu. U novčane se potpore ubrajaju naknada plaće, novčana naknada, novčana pomoć i jednokratna novčana potpora za novorođeno dijete. Navedene potpore ostvaruju majka i otac djeteta, posvojitelj djeteta, skrbnik, udomitelj ili druga fizička osoba kojoj je maloljetno dijete odlukom nadležnog tijela povjereno na čuvanje i odgoj. Ostvariti ih mogu i stranci sa stalnim boravkom u RH, osobe sa statusom azilanta i osobe pod supsidijarnom zaštitom. Za nadzor provedbe ZRRP-a nadležno je Ministarstvo. Ostvarivanje prava iz ZRRP-a u nadležnosti je Hrvatskog zavoda za zdravstveno osiguranje, osim ako prema ZRRP-u za ostvarivanje pojedinih prava nije određeno neko drugo tijelo kao nadležno.

„Novčane potpore ostvarene prema ovom Zakonu ne mogu iznositi manje od $70 \%$ proračunske osnovice utvrđene zakonom o izvršavanju državnog proračuna (u daljnjem tekstu: proračunska osnovica) “ ${ }^{.84}$ Navedeno znači da novčane potpore ne mogu iznositi manje od 2.328,20 kn. Do izmjena i dopuna Zakona koje su na snazi od 1. srpnja 2017. novčane potpore nisu smjele iznositi manje od $50 \%$ proračunske osnovice, odnosno 1.663,00 kn. Nakon 1. srpnja 2017., prema izvješću Ministarstva, zabilježen je znatan porast isplaćenih iznosa za prava iz sustava rodiljnih i roditeljskih potpora, „tako da su prosječna mjesečna izdvajanja počevši od srpnja 2017. nadalje za $23.17 \%$ veća nego prosječna mjesečna izdvajanja u 2016. (u usporedbi s prvim polugodištem 2017. godine, povećanje iznosi $21.06 \%$ )“. .85

83 ZRRP, cit., čl. 1.

84 ZRRP, cit., čl. 4., st. 2.

85 Ministarstvo za demografiju, obitelj, mlade i socijalnu politiku, Privremeno izvješće o korisnicima rodiljnih i roditeljskih potpora i isplaćenim iznosima naknade za siječanj-listopad 2017., dostupno na: https://mdomsp.gov.hr/UserDocsImages/dtomasic/Statisticka\%20 
Isto tako, općina, grad, županija i Grad Zagreb, u svrhu propisanu Zakonom svojim općim aktima mogu propisati način i uvjete za ostvarivanje prava roditelja na novčanu pomoć u većem opsegu od propisanoga Zakonom ili pružanje pomoći u naravi. ${ }^{86}$ Novčanu pomoć ili pomoć u naravi, ako nije u suprotnosti sa ZRRP-om, mogu davati i vjerske zajednice, udruge, trgovačka društva i druge domaće i strane pravne i fizičke osobe radi ostvarivanja svrhe Zakona, a dopušteno je da se u tu svrhu osnivaju zaklade i fondacije. Također, ZRRP izjednačava prava roditelja u bračnoj i izvanbračnoj zajednici, a odnosi se i na druge osobe, odnosno i na roditelje ili njima izjednačene osobe koje se brinu o djetetu, a koje nisu u bračnoj ili izvanbračnoj zajednici. $^{87}$

Prava koja se ostvaruju prema ZRRP-u razlikuju se ovisno o tome je li riječ o zaposlenim ili samozaposlenim roditeljima, roditeljima koji ostvaruju drugi dohodak, roditelju poljoprivredniku koji nije samozaposlen ili nezaposlenim roditeljima ili je riječ o roditeljima koji se nalaze izvan sustava rada. Tijekom korištenja prava iz ZRRP-a zaposleni i samozaposleni roditelji imaju pravo na naknadu plaće. „Naknada plaće određuje se od osnovice za naknadu koju čini prosječni iznos plaće koja je osiguraniku isplaćena u posljednjih šest mjeseci prije mjeseca u kojem je nastupio slučaj na osnovi kojeg se stječe pravo na naknadu plaće, neovisno o tome na čiji se teret isplaćuje, osim u slučaju kada je posebnim zakonom drukčije propisano.“88 Iznosi naknade plaće prema najavama Ministarstva trebali bi se mijenjati, odnosno povećavati već od travnja 2020., te bi se iznos koji se isplaćuje roditeljima tijekom roditeljskog dopusta koji sada iznosi maksimalnih $3.991,20 \mathrm{kn}$ (tablica 7.) trebao povećati na $5.600,00 \mathrm{kn} .{ }^{89}$

Tablica 7. Naknade plaće zaposlenih i samozaposlenih roditelja (izrada autora)

\begin{tabular}{|l|l|}
\hline \multicolumn{1}{|c|}{ Pravo } & \multicolumn{1}{c|}{ Mjesečne naknade plaće } \\
\hline Rodiljni dopust & $\begin{array}{l}\text { pravo na naknadu plaće u iznosu od } 100 \% \text { od osnovice za naknadu } \\
\text { plaće utvrđene prema propisima o obveznom zdravstvenom osiguranju } \\
\text { (isplaćuje se na teret HZZO-a) }\end{array}$ \\
\hline Roditeljski dopust & $\begin{array}{l}8 \text { mjeseci (6 ako koristi jedan roditelj) } 100 \% \text { od osnovice za naknadu } \\
\text { plaće utvrđene prema propisima o obveznom zdravstvenom osiguranju, } \\
\text { ali ne više od } 120 \% \text { proračunske osnovice za puno radno vrijeme } \\
\text { (3.991,20 kn) } \\
\text { Roditeljski dopust kao pravo na rad s polovicom punog radnog vremena } \\
\text { iznosi } 70 \% \text { proračunske osnovice (2.328,20 kn) } \\
\text { Nakon } 8 \text { mjeseci (6 ako dopust koristi jedan roditelj) novčana naknada u } \\
\text { visini od } 70 \% \text { proračunske osnovice }\end{array}$ \\
\hline
\end{tabular}

izvjesca/2017/Privremeno\%20izvjesce $\% 20$ o\%20rodiljnim $\% 20 i \% 20$ roditeljskim $\% 20$ potporama\%20I\%20.-X.\%202017.pdf (23.07.2019.), str. 5.

86 ZRRP, cit., čl. 59., st. 1.

87 ZRRP, cit., čl. 5.

88 Zakon o obveznom zdravstvenom osiguranju, Narodne novine, br. 80/13., 137/13., čl. 54., st. 1.

89 Ministarstvo za demografiju, obitelj, mlade i socijalnu politiku, dostupno na: https://mdomsp. gov.hr/vijesti-8/murganic-povecavamo-roditeljske-naknade-za-drugih-sest-mjeseci-sa-3-991na-5-600-kuna/10938 (20.08.2019.). 


\begin{tabular}{|l|l|}
\hline $\begin{array}{l}\text { Pravo na rad s polovicom } \\
\text { punoga radnog vremena radi } \\
\text { pojačane njege djeteta }\end{array}$ & $\begin{array}{l}\text { pravo na novčanu naknadu u visini od } 70 \% \text { proračunske osnovice } \\
\text { mjesečno za puno radno vrijeme }(2.328,20 \mathrm{kn})\end{array}$ \\
\hline Dopust u slučaju smrti djeteta & $\begin{array}{l}100 \% \text { od osnovice za naknadu plaće utvrđene prema propisima o } \\
\text { obveznom zdravstvenom osiguranju, ali ne više od } 12 \% \text { proračunske } \\
\text { osnovice, iznimno } 100 \% \text { od osnovice za naknadu plaće utvrđene prema } \\
\text { propisima o obveznom zdravstvenom osiguranju }\end{array}$ \\
\hline $\begin{array}{l}\text { Dopust za njegu djeteta do } \\
\text { navršene } 8 \text { godine života } \\
\text { djeteta (dijete s težim } \\
\text { smetnjama u razvoju) }\end{array}$ & $\begin{array}{l}\text { pravo na novčanu naknadu u visini od } 70 \% \text { proračunske osnovice } \\
\text { mjesečno za puno radno vrijeme }(2.328,20 \text { kn) }\end{array}$ \\
\hline Zakonski minimum & $\begin{array}{l}70 \% \text { proračunske osnovice, neovisno je li riječ o punom ili nepunom } \\
\text { radnom vremenu }\end{array}$ \\
\hline
\end{tabular}

Pored toga, najavljen je i pilot projekt produljenog boravka u školama za „koji je izdvojeno 70 milijuna kuna. Škole koje imaju takve mogućnosti moći će organizirati rekreativne, odgojne, kulturne aktivnosti za vrijeme praznika u produljenom boravku. Gradi se i 200 novih vrtića, 252 vrtića su dobila sredstva za poboljšanje materijalnih uvjeta. Ukupno 318 milijuna je izdvojeno i za zapošljavanje odgojitelja“.90

Sljedeća važna demografska mjera u RH je subvencioniranje stambenih kredita mladim obiteljima za kupnju stana ili kuće ili gradnju kuće. Mjera se provodi od 2017. godine. Ministarstvo graditeljstva i prostornog uređenja nove natječaje provodi u jesen 2019. ${ }^{91}$ a planira ih ponoviti i 2020. Riječ je o mjeri kojom se mladima subvencionira dio rate kredita za rješavanje stambenog pitanja u prvih pet godina otplate u određenom postotku koji ovisi o području na kojem se nekretnina nalazi, odnosno ovisi o stupnju razvijenosti područja na kojem se nekretnina nalazi. Naime, subvencija može iznositi od $30 \%$ rate kredita za razvijenija urbana područja kao što su Rijeka ili Zagreb pa do 51 \% iznosa rate kredita za nekretnine kupljene u najslabije razvijenim područjima. ${ }^{92}$ Uvjeti subvencioniranja uređeni su Zakonom o subvencioniranju stambenih kredita ${ }^{93}$ i Naputkom o načinu rada Agencije za pravni promet i posredovanje nekretninama (APN) u provedbi Zakona o subvencioniranju stambenih kredita..$^{95}$ Da je riječ o demografskoj mjeri vidljivo je i iz činjenice da se subvencioniranje kredita produžuje za dvije godine za svako rođeno, odnosno

90 Ministarstvo za demografiju, obitelj, mlade i socijalnu politiku, dostupno na: https://mdomsp. gov.hr/vijesti-8/murganic-u-temi-dana-o-povecanju-roditeljskih-naknada/10939 (23.07.2019.).

91 Središnji državni portal, Subvencioniranje stambenih kredita za mlade, dostupno na: https:// gov.hr/moja-uprava/stanovanje-i-okolis/kupnja-prodaja-i-najam-nekretnine/subvencioniranjestambenih-kredita-za-mlade/1941 (20.09.2019.).

92 Popis svih općina i gradova s postotcima subvencioniranja sukladno s indeksom razvijenosti dostupan je na mrežnim stranicama Ministarstva graditeljstva i prostornog uređenja.

93 Zakon o subvencioniranju stambenih kredita, Narodne novine, br. 65/17., 61/18., 66/19.

94 Naputak o načinu rada Agencije za pravni promet i posredovanje nekretninama u provedbi Zakona o subvencioniranju stambenih kredita, Narodne novine, br. 76/17.

95 Ministarstvo graditeljstva i prostornog uređenja, Subvencioniranje stambenih kredita, Uvjeti subvencioniranja i visina subvencije, dostupno na: https:/mgipu.gov.hr/o-ministarstvu-15/ djelokrug/stanovanje-8130/subvencioniranje-stambenih-kredita-8253/uvjeti-subvencioniranjai-visina-subvencije/8254 (23.07.2019.). 
usvojeno dijete tijekom razdoblja subvencioniranja kredita. Posljednjim izmjenama zakona rok subvencije produžuje se za godinu dana za svako maloljetno dijete koje član kućanstva ili korisnik kredita već ima pri podnošenju zahtjeva. ${ }^{96}$ Prema podatcima Ministarstva graditeljstva i prostornog uređenja „do sada je ovom mjerom stambenog zbrinjavanja više od 5.300 obitelji osiguralo svoj dom, a u tim je obiteljima rođeno preko 550 djece“. .97

Kao što je već navedeno, podatke o provedenim demografskim mjerama općina, gradova i županija u RH prikupilo je i objavilo Ministarstvo za demografiju, obitelj, mlade i socijalnu politiku (vidi supra pozivna bilješka 77). U tablicama su navedeni podatci o iznosima naknada za rođenje djeteta od 2017. do 2019. te druge potpore povezane sa začećem, trudnoćom, novorođenčadi i majčinstvom, sufinanciranjem troškova u području zdravstva, sufinanciranjem vrtića, načinom organizacije upisa u vrtić i rada vrtića, sufinanciranjem školskih udžbenika, sufinanciranjem školske prehrane, sufinanciranjem prijevoza učenika, sufinanciranjem smještaja u učeničke domove, dodjelom stipendija, drugim načinima poticanja studiranja, drugim potporama vezanim za školovanje, mjerama za stambeno zbrinjavanje i ostalo. Kao i u drugim područjima i ovdje možemo reći da, nažalost, u RH razina ostvarivanja socijalnih prava građana znatno ovisi o mjestu stanovanja što je u suprotnosti s jednim od temeljnih načela socijalne države, a to je načelo jednakosti građana u ostvarivanju socijalnih prava. ${ }^{98}$

Iz tablica je vidljivo da samo 11 županija (uključujući i Grad Zagreb) isplaćuje sredstva za rođenje djeteta, a povećanje iznosa koji se isplaćuje za rođenje djeteta od 2017. do 2019., u onim županijama u kojima se isplaćuju sredstva za rođenje djeteta, bilježe Osječko-baranjska i Zadarska županija. Od 128 gradova samo za četiri grada nije navedeno da isplaćuju sredstva za rođenje djeteta (Mali Lošinj, Oroslavje, Sisak i Vodice), a 55 gradova bilježi povećanje sredstava koje isplaćuju za rođenje djeteta od 2017. do 2019. godine.

Po visini naknade koja se isplaćuje za prvo dijete ističu se Imotski, Opatija te Vrlika koji isplaćuju 10.000,00 kn, za drugo dijete također najviše iznose dodjeljuju navedeni gradovi, Imotski 20.000,00 kn, Opatija i Vrlika 15.000,00 kn te Pag i Vis s po $10.000,00 \mathrm{kn}$. Ipak, najveći se iznosi dodjeljuju za troje i više djece. To znači da se iznosi u pravilu povećavaju s povećanjem broja djece u obitelji. Gradovi koji se ističu po visini naknada za treće dijete su: Komiža, Split, Zagreb, Imotski, Crikvenica, Pag, Šibenik, Senj, Opatija, Vrlika i Vis (tablica 8.).

96 Zakon o izmjenama Zakona o subvencioniranju stambenih kredita, Narodne novine, br. 66/19.

97 Vrijednost nekretnine mora iznositi „do najviše 1500 eura po metru kvadratnom odnosno do najvišeg iznosa kredita od 100.000,00 eura u kunskoj protuvrijednosti, a rok otplate kredita ne smije biti kraći od 15 godina.“ Ministarstvo graditeljstva i prostornog uređenja, Subvencioniranje stambenih kredita, dostupno na: https://mgipu.gov.hr/o-ministarstvu-15/ djelokrug/stanovanje-8130/subvencioniranje-stambenih-kredita-8253/8253 (23.07.2019.).

98 Babić, Z., Decentralizacija socijalne skrbi i socijalne nejednakosti: slučaj Hrvatske, Revija za socijalnu politiku, vol. 25, 1/2018, str. 26. 
Tablica 8. Iznosi koje gradovi isplaćuju za rođenje trećega djeteta (izrada autora)

\begin{tabular}{|c|c|}
\hline Komiža (Splitsko-dalmatinska županija) & $\begin{array}{l}120.000,00 \mathrm{kn} \text { za treće i svako sljedeće dijete u obitelji, s } \\
\text { time da omogućuje i stalnu mjesečnu naknadu roditeljima } \\
\text { ili samohranom roditelju djeteta za treće i svako sljedeće } \\
\text { dijete do navršenih } 10 \text { godina života djeteta, } 12.000,00 \\
\text { kn jednokratno i stalna mjesečna naknada } 1.000,00 \mathrm{kn} \\
\text { mjesečno u sljedećih } 9 \text { godina }\end{array}$ \\
\hline Split (Splitsko-dalmatinska županija) & $\begin{array}{l}55.000,00 \mathrm{kn} \text { za treće i svako sljedeće dijete, sljedećih } 10 \\
\text { godina, odnosno } 5.500,00 \mathrm{kn} \text { godišnje }\end{array}$ \\
\hline Grad Zagreb & $\begin{array}{l}54.000,00 \mathrm{kn} \text { za treće i svako sljedeće dijete, u jednakim } \\
\text { obrocima tijekom } 6 \text { godina uz uvjet da oba roditelja imaju } \\
\text { prebivalište u Gradu Zagrebu }\end{array}$ \\
\hline Imotski (Splitsko-dalmatinska županija) & $50.000,00$ kn za treće i svako sljedeće dijete \\
\hline Crikvenica (Primorsko-goranska županija) & $30.000,00$ kn za treće i svako sljedeće dijete \\
\hline Pag (Zadarska županija) & $30.000,00 \mathrm{kn}$ za treće dijete \\
\hline Šibenik (Šibensko-kninska županija) & $\begin{array}{l}21.000,00 \mathrm{kn} \text { za treće i svako sljedeće dijete kroz } 7 \text { godina } \\
\text { u jednakim godišnjim obrocima u mjesecu u kojemu je } \\
\text { rođeno dijete }\end{array}$ \\
\hline Senj (Ličko-senjska županija) & $20.000,00$ kn za treće i svako sljedeće dijete \\
\hline Opatija (Primorsko-goranska županija) & $20.000,00 \mathrm{kn}$ za treće dijete \\
\hline Vrlika (Splitsko-dalmatinska županija) & $20.000,00 \mathrm{kn}$ za treće dijete \\
\hline Vis (Splitsko-dalmatinska županija) & $20.000,00 \mathrm{kn}$ za treće dijete \\
\hline
\end{tabular}

Većina gradova ima jednake iznose za treće i svako sljedeće dijete, ali neki ga gradovi i povećavaju, npr. Pag, Opatija, Vis i Vrlika (tablica 9.).

Tablica 9. Gradovi koji povećavaju iznos naknade za rođenje četvrtog djeteta i iznosi koje isplaćuju (izrada autora)

\begin{tabular}{|l|l|}
\hline Pag (Zadarska županija) & $50.000,00 \mathrm{kn}$ za četvrto dijete \\
\hline Opatija (Primorsko-goranska županija) & $\begin{array}{l}\text { za treće dijete } 30.000,00 \mathrm{kn}, \text { a za svako sljedeće iznos se } \\
\text { povećava za } 5.000,00 \mathrm{kn}\end{array}$ \\
\hline Vis (Splitsko-dalmatinska županija) & $\begin{array}{l}\text { za treće dijete } 20000,00 \mathrm{kn}, \text { a za svako sljedeće iznos se } \\
\text { povećava za } 10000,00 \mathrm{kn}, \\
\text { zanimljivo za Vis je da su iznosi u 2017. i 2018. za treće } \\
\text { dijete bili } 240.000,00 \mathrm{kn} \text { (jednokratno 20.000, 00 kn uz } \\
\text { stalnu mjesečnu novčanu pomoć do djetetove desete godine } \\
\text { života u iznosu } 1.200,00 \mathrm{kn}+\text { jaslice i dječji vrtić, a svako } \\
\text { iduće dijete dobivalo je } 10.000,00 \text { kn više, prema tome } \\
\text { možemo reći da je došlo do smanjenja potpore u } 2019 . \\
\text { godini }\end{array}$ \\
\hline Vrlika (Splitsko-dalmatinska županija) & $25.000,00 \mathrm{kn}$ za četvrto i svako sljedeće dijete \\
\hline
\end{tabular}

Druge potpore koje jedinice lokalne i područne samouprave provode, a vezane su za trudnoću, novorođenčad i majčinstvo odnose se na financiranje različitih tečajeva za trudnice, poklon pakete s potrepštinama za rođeno dijete, financiranje 
prehrane dojenčadi, pakete pelena i dječje robe i slično i uglavnom su vezane uz obitelji slabijeg imovnog stanja. Gradovi sudjeluju i u sufinanciranju dječjih vrtića, a riječ je o subvenciji dijela ekonomske cijene dječjeg vrtića. Iznos subvencije u pravilu ovisi o broju djece iz iste obitelji koje pohađa dječji vrtić. Tako roditelji s više djece u vrtiću ostvaruju pravo na besplatan vrtić ili se cijena smanjuje za drugo ili treće dijete. Cijene ovise i o socijalnim prilikama obitelji, o tome radi li se o djeci s poteškoćama u razvoju, jesu li roditelj samohrani i slično, a postoje i gradovi koji u potpunosti financiraju troškove vrtića pa je on za roditelje besplatan (Belišće, Obrovac, Umag, Vrlika).

Osim pomoći koja se odnosi na trudnice, dojenčad i majčinstvo te djecu predškolskog uzrasta, jedinice lokalne i područne samouprave sudjeluju u provođenju mjera i za djecu u sustavu školovanja. Tako različito sudjeluju u subvencioniranju školske prehrane, prijevoza učenika, smještaju učenika u učeničke domove, dodjeljuju se stipendije učenicima i studentima te novčane pomoći onima koji nisu ostvarili stipendije ili ima je potrebna za odlazak na stručna usavršavanja ili radi otplate studentskih kredita, sufinanciraju se troškovi željezničkog prijevoza studentima i slično.

Na razini područne i lokalne samouprave provode se i određene mjere za stambeno zbrinjavanje, pa tako Varaždinska županija sufinancira najamnine za stanove liječnika Opće bolnice Varaždin, Vukovarsko-srijemska županija sudjeluje u sufinanciranju kupovine prve nekretnine za mlade obitelji. Grad Zagreb u sklopu Zagrebačkog modela stanogradnje, kojim je izgrađeno 1.800 stanova, kod dodjele stanova kao jedan od važnih kriterija uzima broj članova kućanstva, tj. djece. Istodobno gradovi pomažu, posebice obiteljima s više djece, dajući stanove u gradskom vlasništvu u najam, sufinancirajući obnovu nekretnina ili kupnju prve nekretnine, omogućuju niže cijene građevinskih zemljišta u vlasništvu grada, provode izgradnju stanova po modelu poticajne stanogradnje (POS) i dr.

\section{ZAKLJUČAK}

Kao i ostale europske države 21. stoljeća RH se suočava s pojavom novih socijalnih rizika prema kojima je nužno prilagoditi i cjelokupnu socijalnu politiku. Udio se starijeg stanovništva povećava, stopa fertiliteta je niska, broj mladih na tržištu rada se smanjuje. To sve dodatno pogoršava i problem unutarnjih i vanjskih migracija, ponajprije mlađeg i obrazovanog stanovništva, što rezultira usporenim i nejednakim razvojem regija u Hrvatskoj. Osim toga, struktura obitelji se mijenja, povećava se broj obrazovanih žena i žena na tržištu rada, što dovodi do nužnosti za učinkovitim usklađivanjem profesionalnog i obiteljskog života, a time i napuštanjem tradicionalnog oblika obitelji i sve većom potrebom uključivanja muškaraca u privatnu sferu, odnosno brige za kućanstvo i djecu. S time u svezi sve se češće pojavljuje snažnije poticanje korištenja roditeljskog dopusta očeva. S druge strane, stope razvoda su visoke, broj samačkih kućanstava i pojava sve više jedno-roditeljskih obitelji zahtijevaju prilagodbu i promjene u sustavu socijalne sigurnosti.

Kao odgovor na nove rizike EU prihvaća koncept socijalnih investicija kojima 
je glavni cilj osposobiti pojedince da se lakše suočavaju s pojavom socijalnog rizika, a glavna područja ulaganja u tom su konceptu aktivna politika zapošljavanja, obitelj i djeca te obrazovanje. Hrvatska, nažalost, u svim područjima ulaganja zaostaje za državama EU-a, premda su vidljive određene promjene. U području obiteljske politike kao dijelu socijalne politike uočavaju se pozitivni pomaci u povećanju ulaganja u kvalitetu života mladih obitelji u posljednje vrijeme. Naime, dohodovni cenzus za ostvarivanje prava na doplatak za djecu po članu kućanstva povećan je, čime se potencijalno proširio krug korisnika, a novčane potpore više ne mogu biti niže od 70 $\%$ proračunske osnovice. Mjerama Vlade RH najavljena su i nova povećanja naknade tijekom korištenja roditeljskog dopusta što svakako valja pozdraviti, jer će se time i broj očeva uključenih u sustav roditeljskih dopusta povećati. Promjene su uvedene i u području subvencioniranja stambenih kredita mladim obiteljima prema kojima se rok subvencioniranja produžio za godinu dana za svako maloljetno dijete koje član kućanstva ili korisnik kredita već ima pri podnošenju zahtjeva. Svoj doprinos u području obiteljske i populacijske politike u RH daju i jedinice lokalne i regionalne (područne) samouprave tako da se kod mnogih bilježi povećanje sredstava koje ulažu u obitelji u zadnjih nekoliko godina. Prema tome, iako ima još puno prostora za napredak i sustizanje europskog prosjeka po mnogim mjerilima, neki su pozitivni pomaci ipak prisutni u mjerama socijalne politike u RH.

Sve prethodno navedene mjere socijalne su investicije (ulaganja) ponajviše u mlade obitelji te je za očekivati njihov pozitivan učinak. Pritom je iznimna važna osviještenost o izrazito lošem stanju hrvatskoga društva, ponajviše u stvarateljima i predlagateljima odgovarajućih mjera socijalne politike, jer nije dobro rješenje da mjere na lokalnoj razini preuzmu ulogu mjera na državnoj razini budući da će se time dodatno produbiti razlike među korisnicima i adresatima s obzirom na sredinu iz kojeg dolaze. Time se dovodi u pitanje ustavno jamstvo jednakosti svih da uživaju prava sadržana u ustavnoj definiciji RH kao socijalne države.

\section{Knjige i članci:}

\section{LITERATURA}

1. Ajduković, Marina, Rajter, Miroslav, Rezo, Ines, Obiteljski odnosi i roditeljstvo u obiteljima različitog prihoda: kako je život $u$ visokom riziku od siromaštva povezan $\mathrm{s}$ funkcioniranjem obitelji adolescenata, Revija za socijalnu politiku vol. 26, 1/2018, str. 69-94.

2. Akrap, Anđelko i Čipin Ivan, Usklađivanje poslovnoga i obiteljskoga života u Hrvatskoj: utjecaj na fertilitet, Društvena istraživanja, vol. 20, 1/2011, str. 47-68.

3. Babić, Zdenko, Decentralizacija socijalne skrbi i socijalne nejednakosti: slučaj Hrvatske, Revija za socijalnu politiku, vol. 25, 1/2018, str. 25-47.

4. Babić, Zdenko i Baturina, Danijel, Koncept socijalnih investicija kao odgovor na krizu i nove izazove socijalne države: trendovi i perspektive, Revija za socijalnu politiku, vol. 23, 1/2016, str. 39-60.

5. Berit, Brandth i Kvande, Elin, Fathers and flexible parental leave, Work, employment and society, vol. 30, 2/2016, str. 275-290, prema Dobrotić, I., Varga, M., Zašto su važni očevi dopusti i kvote? Komparativni pregled shema dopusta za očeve u europskim zemljama te čimbenika i učinaka njihova korištenja, Revija za sociologiju, vol. 48, 2/2018, str. 209237. 
6. Cousins, Mel, European Welfare States: Comparative Perspectives, London, Sage, 2005. prema Babić Z. i Baturina, D., Koncept socijalnih investicija kao odgovor na krizu i nove izazove socijalne države: trendovi i perspektive, Revija za socijalnu politiku, vol. 23, 1/2016, str. 39-60.

7. Dobrotić, Ivana, Politike usklađivanja obiteljskih obaveza i plaćenog rada i položaj roditelja na tržištu rada, Revija za socijalnu politiku, vol. 22, 3/2015, str. 353-374.

8. Dobrotić, Ivana i Varga, Mirna, Zašto su važni očevi dopusti i kvote? Komparativni pregled shema dopusta za očeve u europskim zemljama te čimbenika i učinaka njihova korištenja, Revija za sociologiju, vol. 48, 2/2018, str. 209-237.

9. Dajak, Lidija i Orešković, Stjepan, Nedostatno korištenje ekonomskih potencijala demografskog starenja u Hrvatskoj, Revija za socijalnu politiku, vol. 25, 1/2018, str. 99105.

10. Hemerjick, Anton, Two or three ways of welfare state transformation, u: Towards a social investment welfare state? Ideas, Policies and Challenges, Nathalie Morel, Bruno Palier, Joakim Palme (ur.) Bristol, The Policy Press, 2012., prema Babić, Z. i Baturina. D., Koncept socijalnih investicija kao odgovor na krizu i nove izazove socijalne države: trendovi i perspektive, Revija za socijalnu politiku, vol. 23, 1/2016, str. 39-60.

11. Knudsen, Herman i Lind, Jens, Danish Flexicurity: Not the Same Today as Yesterday, u: Transnational, European, and National Labour Relations: Flexicurity and New Economy, Gerald G. Sander, Vesna Tomljenović i Nada Bodiroga-Vukobrat (ur.), Cham, Springer, 2018., str. 197-211.

12. Klasić, Ksenija, Utjecaj rodne podjele obiteljskih obveza i kućanskih poslova na profesionalni život zaposlenih žena, Zagreb, Pravobranitelj/ica za ravnopravnost spolova Republike Hrvatske, 2017.

13. Pennings, Frans, Dilemmas in Organising the Labour Market, Experiences with Flexicurity in the Netherlands u: Transnational, European, and National Labour Relations: Flexicurity and New Economy, Gerald G. Sander, Vesna Tomljenović i Nada BodirogaVukobrat (ur.), Cham, Springer, 2018., str. 213-222.

14. Puljiz, Vlado, Bežovan, Gojko, Šućur, Zoran, Zrinščak, Siniša, Socijalna politika, Zagreb, Pravni fakultet, 2005.

15. Puljiz, Vlado, Bežovan, Gojko, Matković, Teo, Šućur, Zoran, Zrinščak, Siniša, Socijalna politika Hrvatske, Zagreb, Pravni fakultet, 2008.

16. Puljiz, Vlado, Starenje stanovništva - izazov socijalne politike, Revija za socijalnu politiku, vol. 23, 1/2016, str. 81-98.

17. Rubinić, Ivan i Tajnikar, Maks, Labour force exploitation and unequal labour excahnge as the root cause of the Eurozone's inexuality, Društvena istraživanja, vol. 28, 2 /2019, str. 207-228.

18. Stropnik, Nada, Obiteljske politike u Europi, Revija za socijalnu politiku, vol. 3, 2/1996, str. 105-111, prema Puljiz, Vlado, Obiteljska politika, u: Socijalna politika, Puljiz, Vlado, Bežovan, Gojko, Šućur, Zoran, Zrinščak, Siniša, Socijalna politika, Zagreb, Pravni fakultet, 2005.

19. Učur, Marinko Đ. Socijalno pravo, Zagreb, Informator, 2000. 


\author{
Vanja Smokvina* \\ Magdalena Čunčić**
}

Summary

\title{
CONTEMPORARY CHALLENGES IN SOCIAL POLICY IMPLEMENTATION WITH PARTICULAR EMPHASIS ON SOCIAL INTERVENTION MEASURES
}

In this paper the authors give special attention to the measures of social interventions as measures of social policy in line to fight the present challenges of the contemporary society. Special attention is given to the measures of child allowances, parental benefits, state subsidies for residential loans for young families and other measures of pro-natal and family policy not just at the state level but also at local municipality level.

Keywords: social policy; social investments; Croatia; European Union.

Zussamenfassung

\section{MODERNE HERAUSFORDERUNGEN BEI DER DURCHFÜHRUNG DER SOZIALPOLITIK MIT BESONDERER BETONUNG AUF DIE MASSNAHMEN DER SOZIALEN INTERVENTION}

Dieser Beitrag bespricht die Wichtigkeit von sozialen Interventionen als Maßnahmen der Sozialpolitik bei der Bewältigung der Herausforderungen moderner Gesellschaft. Die Maßnahmen wie Kindergeld, Mutterschaftsgeld, Subventionierung von Wohnungskrediten junger Familien und andere Maßnahmen der Geburten- und Familienpolitik nicht nur auf nationaler sondern auch auf lokaler Ebene werden hervorgehoben.

Schlüsselwörter: Sozialpolitik; soziale Investitionen; Kroatien; die EU.

\footnotetext{
* Vanja Smokvina, Ph.D., Assistant Professor, Univeristy of Rijeka, Faculty of Law; vsmokvina@ pravri.com.

** Magdalena Čunčić, mag. iur.; magdalenacuncic@gmail.com.
} 
Riassunto

\section{LE SFIDE CONTEMPORANEE NELLA REALIZZAZIONE DELLE POLITICHE SOCIALI CON PARTICOLARE ATTENZIONE PER LE MISURE DI INTERVENTO SOCIALE}

Nel lavoro gli autori sottolineano l'importanza degli interventi sociali quali misure di politica sociale volte a superare le sfide poste dinnanzi alla società contemporanea. L'accento viene posto su misure quali gli aiuti ai minori, l'indennità per il congedo parentale, le sovvenzioni rivolte alle giovani famiglie per i mutui su immobili, altre misure volte alla natalità, come pure sulle politiche familiari statali e locali.

Parole chiave: politica sociale; investimenti sociali; Croazia sociale; UE. 